\title{
Evidence for differential alternative splicing in blood of young boys with autism spectrum disorders
}

\author{
Boryana S Stamova ${ }^{1,2,5^{*}}$, Yingfang Tian ${ }^{1,2,4}$, Christine W Nordahl ${ }^{1,3}$, Mark D Shen ${ }^{1,3}$, Sally Rogers ${ }^{1,3}$,
} David G Amaral ${ }^{1,3}$ and Frank R Sharp ${ }^{1,2}$

\begin{abstract}
Background: Since RNA expression differences have been reported in autism spectrum disorder (ASD) for blood and brain, and differential alternative splicing (DAS) has been reported in ASD brains, we determined if there was DAS in blood mRNA of ASD subjects compared to typically developing (TD) controls, as well as in ASD subgroups related to cerebral volume.

Methods: RNA from blood was processed on whole genome exon arrays for 2-4-year-old ASD and TD boys. An ANCOVA with age and batch as covariates was used to predict DAS for ALL ASD ( $n=30)$, ASD with normal total cerebral volumes (NTCV), and ASD with large total cerebral volumes (LTCV) compared to TD controls $(n=20)$.

Results: A total of 53 genes were predicted to have DAS for ALL ASD versus TD, 169 genes for ASD_NTCV versus TD, 1 gene for ASD_LTCV versus TD, and 27 genes for ASD_LTCV versus ASD_NTCV. These differences were significant at $P<0.05$ after false discovery rate corrections for multiple comparisons (FDR $<5 \%$ false positives). A number of the genes predicted to have DAS in ASD are known to regulate DAS (SFPQ, SRPK1, SRSF11, SRSF2IP, FUS, LSM14A). In addition, a number of genes with predicted DAS are involved in pathways implicated in previous ASD studies, such as ROS monocyte/macrophage, Natural Killer Cell, mTOR, and NGF signaling. The only pathways significant after multiple comparison corrections (FDR <0.05) were the Nrf2-mediated reactive oxygen species (ROS) oxidative response (superoxide dismutase 2, catalase, peroxiredoxin 1, PIK3C3, DNAJC17, microsomal glutathione S-transferase 3) and superoxide radical degradation (SOD2, CAT).

Conclusions: These data support differences in alternative splicing of mRNA in blood of ASD subjects compared to TD controls that differ related to head size. The findings are preliminary, need to be replicated in independent cohorts, and predicted alternative splicing differences need to be confirmed using direct analytical methods.
\end{abstract}

Keywords: Autism, ASD, RNA, Splicing, Head size, Gene expression

\section{Background}

Autism spectrum disorder (ASD) is a spectrum of neurodevelopmental disorders that are clinically defined by communication and social impairments combined with stereotypic and repetitive behaviors [1]. Though over $20 \%$ of those diagnosed with ASD have a number of identifiable genetic causes [2], the genetic bases for

\footnotetext{
* Correspondence: boryana.stamova@ucdmc.ucdavis.edu

'MIND Institute, University of California at Davis, Sacramento, CA 95817, USA ${ }^{2}$ Department of Neurology, University of California at Davis, Sacramento, CA 95817, USA

Full list of author information is available at the end of the article
}

the remaining cases remain unclear. It is not known how many other genetic causes of ASD may be identified, or if there is a group of susceptibility genes that interact with environmental factors (for example, toxins, infection, immune) and cause the majority of cases of ASD [2-4].

A role for both genetics and environment in ASD has come from many studies, including a recent study of ASD brain. Regional patterns of gene expression that distinguish frontal and temporal cortex were attenuated in ASD brain compared to controls [5]. Moreover, there were two modules of co-expressed genes associated with

\section{Biomed Central}


autism including a neuronal module enriched for known autism susceptibility genes (genetic module); and a module enriched for immune and glial genes that were not enriched for autism GWAS-associated genes (environmental immune module) [5]. Significantly for the present study, some genes showed evidence of altered differential alternative splicing (DAS) of specific FOX1 regulated mRNAs [5].

These data led us to consider in this study whether there might be altered DAS of mRNA in ASD blood. Blood is useful to study in ASD for several reasons: (1) various factors - including genetics, toxicants, infections, immune and autoimmune factors implicated in ASD [6-11] - affect alternative splicing in leukocytes in blood [12-19]; (2) the monocyte transcriptome in blood is very similar to the microglia (brain macrophage) transcriptome $[20,21]$, and microglia are activated in ASD brain [22]; (3) immune and autoimmune dysfunction that would be associated with alterations of gene expression and alternative splicing in blood has been reported in subgroups of ASD individuals [23-26]; (4) there is crosstalk between the immune system and the CNS $[27,28]$; (5) studies of blood allow us to investigate subjects at an early age when ASD becomes clinically evident.

In recruiting subjects for this study, we included ASD boys that were ultimately found to have altered trajectories of brain development. Abnormal brain enlargement has been consistently observed in MRI studies of preschool-aged ASD children compared to age-matched controls [29-31]. This is one of the most consistent findings in the neuropathology of a subset of ASD in boys, however there is considerable variability in total cerebral volume (TCV) phenotypes. Macrocephaly has been reported in $15 \%$ to $20 \%$ of young children with ASD [29,31-34] , though there is an ongoing debate for its relevance in ASD [35,36]. In the larger population of children recruited for this study, approximately $15 \%$ had abnormally enlarged TCV [30]. In addition, PTEN (phosphatase and tensin homolog deleted on chromosome 10) mutations are found in a subset of ASD children with macrocephaly [37-39]. It has been suggested that PTEN may regulate cell size through effects on protein translation, particularly interesting in the view of its connection to $\mathrm{PI} 3 \mathrm{~K} / \mathrm{AKT} / \mathrm{mTOR}$ signaling pathways implicated in single gene causes of ASD [40]. Finally, differences of differential alternative splicing have been associated with abnormal brain volumes in various animal models and in humans [41-44].

We therefore postulated that specific differences in alternative splicing/exon usage in immune blood cells may be present in ASD boys, and this might differ in ASD boys with large total cerebral volumes (ASD_LTCV) versus ASD boys with normal total cerebral volumes (ASD_NTCV). Thus, we compared ASD and ASD subgroups related to total cerebral volume to typically developing (TD) controls. Our findings demonstrate DAS in ASD versus TD boys, and that there are differences of DAS in ASD boys with large brains compared to those with normal total cerebral volumes. Finally, there are some genes that demonstrate DAS in blood in this study that have previously been reported to have DAS in brain [5]. However, most of the DAS blood genes are different from DAS brain genes which would be consistent with differential alternative splicing generally being tissue specific [45-48].

\section{Methods}

\section{Subjects}

This study was approved by the University of California at Davis Institutional Review Board (IRB). Written informed consent was obtained from the parent or guardian of each participant and data were analyzed without personal information identifiers.

Fifty boys ( $n=20$ TD and $n=30$ ASD), aged $2-4$ years, participated in this study. Participants were enrolled in the UC Davis MIND Institute's Autism Phenome Project (APP) (http://www.ucdmc.ucdavis.edu/mindinstitute/research/app/). The diagnostic criteria for ASD and TD and inclusion and exclusion criteria were previously described [30]. Briefly, subjects were recruited through the MIND Institute at the University of California, Davis. ASD diagnosis was determined based on administration of the Autism Diagnostic Observation Schedule-Generic (ADOS-G) [49], and the Autism Diagnostic InterviewRevised (ADI-R) [50] by appropriately trained members of the research team and clinical consensus of two independent psychologists. Autism severity was determined by using the ADOS severity score, based on the algorithm scores on the various modules [51]. Developmental abilities of cases and controls were determined using the Mullen Scales of Early Development [52]. In addition, several inclusion and exclusion criteria were used for the TD group. TD inclusion was based on having Standard Score of 70-130 on the Learning Composite of the Mullens Scale of Early Learning, and a score $<11$ on the Social Communication Questionnaire used to screen for autism traits [53]. Exclusion criteria for the TD group included a diagnosis of intellectual disability, pervasive developmental disorder, specific language impairment, or any known developmental, neurological, or behavioral problems [30].

In addition, if the ASD or TD children had a fever or had been ill within the 2 weeks before the blood draw, blood draws were rescheduled for a later time. This method was used to exclude children with acute infections in a previous CHARGE study [54]. Clinical information collected for the kids from this study showed six were on different prescription and non-prescription 
medications (6 ASD/0 TD), and 25 (17 ASD/8 TD) were on supplements (mostly vitamins). Since no two ASD or TD individuals were on the same medication or supplement, and times varied since the last doses, these were not included as covariates in the analyses and there were too few medication- and supplement-free subjects to analyze separately.

\section{MRI of brain}

Because total cerebral volume (TCV) is extremely variable in ASD [30], ASD participants were selected to have a range of TCV. As part of the APP, all participants underwent MRI scanning at the UC Davis Imaging Research Center, as previously described [30]. In short, all scans were acquired during natural, nocturnal sleep. Total cerebral volume (TCV) data were measured from a three-dimensional T1-weighted MPRAGE scan (TR, 2,170 ms; TE, $4.86 \mathrm{~ms}$; matrix, $256 \times 256$; slices acquired in sagittal direction, 192; isotropic voxels, $1 \mathrm{~mm}$ ). Distortion correction using a calibration phantom was carried out and images were corrected for field in homogeneity. TCV was measured using a template-based automated method, and excluded brainstem and cerebellum [30]. ASD subjects were divided into two subgroups based on MRI measures of TCV, with the ones with NTCV $(n=20$ ASD subjects) having TCV within 1.5 standard deviations of the TD centroid [30], while the ones with LTCV $(n=10)$ had TCV $>1.5$ standard deviations of the TD controls.

\section{RNA and array processing}

Whole venous blood was collected into PAXgene tubes (PreAnalytiX, Germany), which immediately lyse all cells in whole blood and stabilize the RNA without measurable degradation or ex vivo transcriptional changes. RNA was isolated and processed as previously described [55] using the WT-Ovation ${ }^{\text {Tx }}$ Pico RNA Amplification System (NuGEN, San Carlos, CA, USA) with the Exon Module and fragmented and labeled using the FL Ovation ${ }^{\text {Tu }}$ cDNA Biotin Module V2 (NuGEN, San Carlos, CA, USA). Expression was measured by hybridization on Affymetrix Human Exon 1.0 ST microarrays according to protocol (Affymetrix, Santa Clara, CA, USA).

Probe summarization and probe set normalization were performed using robust multi-chip average (RMA) in Partek Genomics Suite 6.5 software (Partek Inc., St. Louis, MO, USA). RMA includes background correction, Quantile Normalization, $\log _{2}$-transformation, and Median Polish probe set summarization. Only the core meta-probe sets (about 228,000 probe sets) were analyzed since these are the best annotated. Exons with low signal in all samples (maximum signal across all samples of the $\log _{2^{-}}$ transformed probe set value $<3$ ), were considered not expressed and were excluded from further analysis.

\section{Analysis of predicted DAS}

Since the exon array used does not contain probe sets covering exon-exon junctions, deducing DAS is indirect given that the unit measured is exon expression which provides a measure of exon usage. Thus we will often use the term predicted 'differential alternative splicing/ differential exon usage (DAS/DEU)' to emphasize the fact that differential exon expression is used to predict DAS in these studies.

An alternative splicing ANCOVA was performed on the probe sets passing the filtering criteria using Partek software. The Splicing ANCOVA Model [56,57] used was:

$$
\begin{aligned}
\mathrm{Y}_{\mathrm{ijklm}}=\mu & + \text { Group }_{\mathrm{i}}+\text { Age } \text { Batch }_{\mathrm{j}}+\text { MarkerID }_{\mathrm{k}} \\
& +{\text { SampleID }(\text { Group } * \text { Batch })_{\mathrm{ijl}}} \\
& + \text { Group } \text { MarkerID }_{\mathrm{ik}}+\text { Age } * \text { MarkerID }_{\mathrm{k}} \\
& + \text { Batch } * \text { MarkerID }_{\mathrm{jk}}+\varepsilon_{\mathrm{ijklm}}
\end{aligned}
$$

Where:

- $\mathrm{Y}_{\mathrm{ijk} k \mathrm{~m}}$ represents the $\mathrm{m}^{\text {th }}$ observation on the $\mathrm{i}^{\text {th }}$ Group, $j^{\text {th }}$ Batch, $k^{\text {th }}$ MarkerID, ${ }^{\text {th }}$ SampleID.

- $\mu$ is the common effect for the whole experiment.

- $\varepsilon_{\mathrm{ijklm}}$ represents the random error present in the $\mathrm{m}^{\text {th }}$ observation on the $i^{\text {th }}$ Group, $j^{\text {th }}$ Batch, $k^{\text {th }}$ MarkerID, $\mathrm{l}^{\text {th }}$ SampleID. The errors $\varepsilon_{\mathrm{ijklm}}$ are assumed to be normally and independently distributed with mean 0 and standard deviation $\delta$ for all measurements.

SampleID(Group * Batch) ${ }_{\mathrm{ijl}}$ is a sample-to-sample effect. SampleID is a random effect. Batch is a random effect.

MarkerID $\mathrm{k}_{\mathrm{k}}$ is exon-to-exon effect (alt-splicing independent to Group). This term also accounts for the fact that not all exons of a gene hybridize to the corresponding probe sets (MarkerID) with the same efficiency.

Group * MarkerID $D_{\mathrm{ik}}$, Age * MarkerID $\mathrm{D}_{\mathrm{k}}$, Batch * MarkerID $D_{j k}$ represent whether an exon expresses differently in different level of the specified alternative splice factor(s). The term Group * MarkerID ${ }_{\mathrm{ik}}$ was used to identify group-specific DAS.

Thus, an alternative splicing ANCOVA was performed on the 17,100 genes passing the filtering criteria (maximum signal across all samples of the log2-transformed probe set value $<3$, as described in the above section). The splicing ANCOVA model included covariates for both technical (batch, random effect) and biological (age, continuous variable) variation to account for their effect on DAS/DEU. In addition, since not all exons in a gene express/hybridize to the probe sets at the same level, MarkerID was added to the model to account for exon-to -exon differences. MarkerID is an exon-to-exon effect (alt- 
splicing independent of Group). SampleID was added to the model, which accounted for the sample-to-sample effect. An interaction term of MarkerID with Group (ASD, TD) to detect alternative splicing was used to estimate an exon has a different expression in different levels of the factor (ASD, TD), which was used to identify genes with predicted DAS/DEU in the different groups. The splicing prediction algorithm within Partek software was used.

Separate differential alternative splicing ANCOVAs were performed for the following comparisons: All ASD versus TD; ASD_LTCV versus TD; ASD_NTCV versus TD; and ASD_NTCV versus ASD_LTCV. To correct for the multiple comparisons being performed, a BenjaminiHochberg false discovery rate of $5 \%$ was adopted, meaning that the $P$ values were adjusted so that no more than $5 \%$ of the reported genes would be expected to be false positives [58].

\section{Hierarchical clustering and principal component analyses} Hierarchical clustering using Euclidean distance and average linkage, and the principal components analysis (PCA) were performed in Partek Genomics Suite. For each analysis, the exon-level expression data corrected for age and batch were used. Genome-wide PCA using all probe sets on the array and all samples was performed to examine array quality and visualize variability at the whole-genome level (Additional file 1: Figure S1).

\section{Functional pathways associated with DAS in ASD}

Ingenuity pathway analysis (IPA) was used to identify the pathways from the IPA library of canonical pathways that were most significant to each dataset. The significance of the association between the dataset with predicted DAS/DEU and canonical pathways was assessed by calculating the ratio of the number of genes from the dataset that map to the pathway divided by the total number of molecules that exist in the canonical pathway. A Fisher's exact test was then used to calculate a $P$ value determining the probability that each biological function and/or pathway assigned to that dataset is due to chance alone. A FDR (5\% false positives) corrected $P<0.05$ was considered to be statistically significant for over-representation of the molecules in a given pathway. Thus, over-represented canonical pathways are those with more molecules than expected by chance.

The above analyses used standard criteria for identifying ASD pathways associated with DAS/DEU. However, as outlined in the results below, only two pathways were identified using the DAS/DEU genes that passed FDR correction. We therefore performed a sub-analysis in order to obtain a broader picture of possible regulated pathways. Thus, a splicing ANCOVA was performed for
All ASD versus TD, except that all genes showing a $P<0.05$ for DAS were identified. An exon-level expression ANCOVA was then performed on these genes for ALL ASD versus TD, including age and batch as covariates. Exons with expression significantly different between All ASD and TD with $P<0.005$ and |FoldChange| $>1.2$ were considered significant in this analysis. This approach would help correct for multiple comparisons and should identify the most reliable DAS genes because they were predicted to be differentially alternatively spliced, and to have significant differences of exon-level expression for All ASD versus TD (overlap $P<0.0002)$. An Ingenuity pathway analysis was then performed on this list of genes for ALL ASD versus TD with $P<0.05$ considered significant.

\section{Results}

\section{Participants' characteristics}

Demographic and clinical characteristics of the subjects are presented in Table 1. There were 20 ASD_NTCV subjects (3.0 \pm 0.5 years), 10 ASD_LTCV subjects (3.1 \pm 0.2 years), and 20 TD subjects $(3.0 \pm 0.3$ years $)$. Seven out of the 10 ASD_LTCV subjects were classified as megalencephalic, defined as having TCV $>2$ standard deviations above the TD mean. There were no significant group differences in age or race. As expected, developmental quotient (DQ), verbal quotient (VQ), and nonverbal quotient (NVQ) were significantly lower in the ASD than the TD groups $(P<1 \mathrm{E}-09)$. Total cerebral volume (TCV) was not significantly different between the ASD_NTCV and TD groups $(P=0.87)$. TCV was significantly enlarged in the ASD_LTCV compared to ASD_NTCV $(P=2.42 \mathrm{E}-10)$ and TD $(P=1.42 \mathrm{E}-09)$, which was the result of our pre-selection. There were no significant differences in the ADOS severity scores between the ASD_NTCV and ASD_LTCV groups $(P=0.17)$.

\section{DAS/DEU in ASD groups compared to TD}

There were 53 genes with predicted DAS/DEU for the comparisons of ALL ASD versus TD (Table 2, Additional file 2: Table S1) (FDR corrected $P<0.05$ ). The cluster analysis (Figure 1A) and Principal Components Analysis (Figure 1B) using these genes demonstrated good separation of the subjects in each group with a few exceptions (Figure 1).

There were 169 genes with predicted DAS/DEU for the comparisons of ASD_NTCV versus TD (FDR corrected $P<0.05$ ) (Additional file 2: Table S2). The cluster analysis (Figure 2A) and principal components analysis (Figure 2B) using these genes demonstrated excellent separation of the subjects in each group with no exceptions (Figure 2).

There was only one gene with predicted DAS/DEU for the comparison of ASD_LTCV versus TD (FDR corrected 
Table 1 Demographic and clinical characteristics of autism spectrum disorder (ASD) and typically developing (TD) participants

\begin{tabular}{|c|c|c|c|c|}
\hline & TD & ASD & $\begin{array}{l}\text { ASD } \\
\text { Normal } \\
\text { TCV }\end{array}$ & $\begin{array}{l}\text { ASD } \\
\text { Enlarged } \\
\text { TCV }\end{array}$ \\
\hline \multicolumn{5}{|l|}{$n$} \\
\hline Subjects & 20 & 30 & 20 & 10 \\
\hline \multicolumn{5}{|l|}{ Age (years) } \\
\hline Mean \pm SD & $3.0 \pm 0.3$ & $2.9 \pm 0.4$ & $3.0 \pm 0.5$ & $3.1 \pm 0.2$ \\
\hline \multicolumn{5}{|l|}{ Gender } \\
\hline Male, $n(\%)$ & $20(100 \%)$ & $30(100 \%)$ & $20(100 \%)$ & $10(100 \%)$ \\
\hline \multicolumn{5}{|l|}{ Race, $n$ (\%) } \\
\hline White & $14(70 \%)$ & $15(50 \%)$ & $11(55 \%)$ & $4(40 \%)$ \\
\hline Black & $0(0 \%)$ & $3(10 \%)$ & $2(10 \%)$ & $1(10 \%)$ \\
\hline Asian & $0(0 \%)$ & $1(3 \%)$ & $1(5 \%)$ & $0(0 \%)$ \\
\hline Other & $0(0 \%)$ & $1(3 \%)$ & $1(5 \%)$ & $0(0 \%)$ \\
\hline Mixed & $3(15 \%)$ & $2(7 \%)$ & $1(5 \%)$ & $1(10 \%)$ \\
\hline Unknown & $3(15 \%)$ & $8(27 \%)$ & $4(20 \%)$ & $4(40 \%)$ \\
\hline \multicolumn{5}{|l|}{ TCV (cm3) } \\
\hline Mean \pm SD & $\begin{array}{l}994.8 \pm \\
65.0\end{array}$ & $\begin{array}{l}1049.7 \pm \\
87.4 \\
\end{array}$ & $\begin{array}{l}997.7 \pm \\
51.0\end{array}$ & $\begin{array}{l}1153.7 \pm \\
33.6\end{array}$ \\
\hline \multicolumn{5}{|c|}{ ADOS Severity Score } \\
\hline Mean \pm SD & NA & $8.0 \pm 1.7$ & $8.3 \pm 1.7$ & $7.4 \pm 1.6$ \\
\hline \multicolumn{5}{|c|}{$\begin{array}{l}\text { Developmental } \\
\text { quotient (DQ) }\end{array}$} \\
\hline Mean \pm SD & $\begin{array}{l}106.6 \pm \\
14.0\end{array}$ & $\begin{array}{l}60.2 \pm \\
22.7 \\
\end{array}$ & $\begin{array}{l}61.4 \pm \\
20.9\end{array}$ & $\begin{array}{l}57.7 \pm \\
27.0\end{array}$ \\
\hline \multicolumn{5}{|c|}{ Verbal quotient (VQ) } \\
\hline Mean \pm SD & $\begin{array}{l}109.5 \pm \\
15.6\end{array}$ & $\begin{array}{l}53.6 \pm \\
28.2\end{array}$ & $\begin{array}{l}54.4 \pm \\
25.9\end{array}$ & $\begin{array}{l}52.1 \pm \\
33.8\end{array}$ \\
\hline \multicolumn{5}{|c|}{$\begin{array}{l}\text { Nonverbal quotient } \\
\text { (NVQ) }\end{array}$} \\
\hline Mean \pm SD & $\begin{array}{l}103.6 \pm \\
14.6\end{array}$ & $\begin{array}{l}66.7 \pm \\
19.9\end{array}$ & $\begin{array}{l}68.4 \pm \\
18.9\end{array}$ & $\begin{array}{l}63.3 \pm \\
22.5\end{array}$ \\
\hline
\end{tabular}

$P<0.05)$. This was C19orf6 (Chromosome 19 open reading frame 6) which is also called membralin (MBRL).

There were 27 genes with predicted DAS/DEU for the comparisons of ASD_LTCV versus ASD_NTCV (FDR corrected $P<0.05)$ (Table 3, Additional file 2: Table S3). The cluster analysis (Figure 3A) and principal components analysis (Figure 3B) using these 27 genes demonstrated excellent separation of the subjects in each group (Figure 3).

\section{Pathway analyses}

Pathway analysis on each of the above lists of genes showed that only two pathways were significantly different at $P<0.05$ after FDR correction for multiple comparisons (FDR $<5 \%$ false positives). These two pathways were for the 53 genes for ALL ASD versus TD comparison and included: (1) the Nrf2-mediated oxidative stress response (SOD2, CAT, PRDX1, PIK3C3, DNAJC17, and MGST3); and (2) the superoxide radical degradation (SOD2, CAT). This pathway analysis was supplemented by a network analysis which considered all of the up- and downregulated FDR passing genes and included direct as well as indirect interactions. The number one network for All ASD versus TD was: Free Radical Scavenging, Cell Death and Survival, Small Molecule Biochemistry (Additional file 1: Figure S2), which had PI3K as one of the central hubs. Notably, the second highest scoring network in ASD_LTCV versus ASD_NTCV included genes involved in RNA post-transcriptional modification with Ubiqiutin $\mathrm{C}$ as a central hub of direct interactions (Additional file 1: Figure S3).

As described in the Methods section, we performed a sub-analysis to identify additional pathways associated with ASD versus TD. There were 477 genes predicted to have DAS between ALL ASD versus TD $(P<0.05)$ and that had significant differences in exon expression between ASD and TD $(P<0.005)$ and a fold change of at least 1.2 or more (Additional file 2: Table S4). IPA analysis of these 477 genes revealed 21 pathways that were significantly different for ALL ASD versus TD $(P<0.05)$ (Additional file 2: Table S5).

We then determined which of the 21 pathways were dysregulated in each ASD individual. To do this unique analysis, PCA mapping was performed based on exonlevel expression of the genes predicted to have DAS/ DEU in each pathway found to be over-represented with genes with DAS/DEU. For example, the PCA plot of the mTOR signaling pathway (Figure 4, upper right inset) was based on the expression level of eight exons in mTOR genes predicted to have DAS/DEU (Additional file 2: Table S5). Based on the PCA position of each ASD subject, the mTOR signaling pathway was scored as TD-like (if within 2 standard deviations of the TD centroid), or non-TD-like (if outside the 2 standard deviations of the TD centroid) (Figure 4, upper right inset). The same procedure was then performed for each of the 21 significantly over-represented canonical pathways, with each individual being assigned either as being 'TDlike ASD' (black rectangles) or 'non-TD-like ASD' (gray rectangles) for each pathway (Figure 4). Hierarchical clustering of the ASD subjects and the 21 canonical pathways (Figure 4) showed that different combinations of pathways were affected (non-TD-like ASD, gray rectangles) in different ASD subjects (Figure 4). No pathway was affected in every subject. Five ASD subjects had all 21 pathways affected (Figure 4, right side of $x$-axis cluster), but there were some ASD subjects with only several pathways affected (Figure 4, left side of $\mathrm{x}$-axis cluster). The pathways affected in the majority of the ASD 
Table 2 Genes ( $n=53$ ) with predicted DAS/DEU in All ASD vs. TD groups (FDR $P<0.05$ )

\begin{tabular}{|c|c|c|c|c|c|}
\hline & \multirow{3}{*}{$\begin{array}{l}\text { CC2D1A } \\
\text { STAT4 }\end{array}$} & \multirow{3}{*}{$\begin{array}{l}\text { Coiled-coil and C2 domain containing } 1 \text { A } \\
\text { Signal transducer and activator } \\
\text { of transcription } 4\end{array}$} & \multirow{3}{*}{$\begin{array}{l}4.49 \mathrm{E}-02 \\
4.49 \mathrm{E}-02\end{array}$} \\
\hline $\begin{array}{l}\text { Gene } \\
\text { symbol }\end{array}$ & Jen & $\begin{array}{l}\text { FDR } P \\
\text { (DAS) }\end{array}$ & & & \\
\hline CDK13 & Cyclin-dependent kinase 13 & $5.50 \mathrm{E}-05$ & & & \\
\hline USP48 & Ubiquitin specific peptidase 48 & 1.11E-03 & $\mathrm{DH} 229$ & DEAH (Asp-Glu-Ala-His) box polypeptide 29 & 4.51E-02 \\
\hline SFPQ & Splicing factor proline/glutamine-rich & $1.11 \mathrm{E}-03$ & MGST3 & Microsomal glutathione S-transferase 3 & 4.51E-02 \\
\hline FXR1 & $\begin{array}{l}\text { Fragile } \mathrm{X} \text { mental retardation, } \\
\text { autosomal homolog } 1\end{array}$ & $1.11 \mathrm{E}-03$ & TEPP & Testis, prostate, and placenta expressed & 4.51E-02 \\
\hline C19orf6 & Chromosome 19 open reading frame 6 & $1.85 \mathrm{E}-03$ & UTRN & Utrophin & 4.51E-02 \\
\hline CAT & Catalase & $1.85 \mathrm{E}-03$ & PUM2 & Pumilio homolog 2 (Drosophila) & 4.51E-02 \\
\hline ZNF330 & Zinc finger protein 330 & 1.85E-03 & CHID1 & Chitinase domain containing 1 & 4.51E-02 \\
\hline C19orf2 & Chromosome 19 open reading frame 2 & $1.85 \mathrm{E}-03$ & GFER & $\begin{array}{l}\text { Growth factor, augmenter of liver } \\
\text { regeneration }\end{array}$ & 4.51E-02 \\
\hline TARS2 & $\begin{array}{l}\text { Threonyl-tRNA synthetase } 2 \text {, } \\
\text { mitochondrial (putative) }\end{array}$ & 3.66E-03 & RPGR & Retinitis pigmentosa GTPase regulator & 4.51E-02 \\
\hline LRPPRC & Leucine-rich PPR-motif containing & $3.86 \mathrm{E}-03$ & SUCLA2 & $\begin{array}{l}\text { Succinate-CoA ligase, ADP-forming, } \\
\text { beta subunit }\end{array}$ & $4.72 \mathrm{E}-02$ \\
\hline $\mathrm{PIK} 3 \mathrm{C} 3$ & Phosphoinositide-3-kinase, class 3 & $4.65 \mathrm{E}-03$ & ZNF512B & Zinc finger protein $512 \mathrm{~B}$ & $4.72 \mathrm{E}-02$ \\
\hline CLTB & Clathrin, light chain B & $5.13 \mathrm{E}-03$ & MORN2 & MORN repeat containing 2 & 4.72E-02 \\
\hline SOD2 & Superoxide dismutase 2, mitochondrial & $6.11 \mathrm{E}-03$ & \multirow[t]{2}{*}{ DNAJC17 } & \multirow{2}{*}{$\begin{array}{l}\text { DnaJ (Hsp40) homolog, subfamily } \\
\text { C, member } 17\end{array}$} & \multirow[t]{2}{*}{ 4.88E-02 } \\
\hline \multirow[t]{2}{*}{ OS9 } & \multirow{2}{*}{$\begin{array}{l}\text { Osteosarcoma amplified 9, endoplasmic } \\
\text { reticulum lectin }\end{array}$} & \multirow[t]{2}{*}{$6.11 \mathrm{E}-03$} & & & \\
\hline & & & FGD3 & FYVE, RhoGEF and PH domain containing 3 & 4.88E-02 \\
\hline
\end{tabular}

ACPT Acid phosphatase testicular

PPP2R2A Protein phosphatase 2 , regulatory subunit B, alpha

C14orf159 Chromosome 14 open reading frame 159

FGR Gardner-Rasheed feline sarcoma viral ( $v$-fgr) oncogene homolog

GSN - Gelsolin

EAPP E2F-associated phosphoprotein

PIP4K2A Phosphatidylinositol-5-phosphate

4-kinase, type II, alpha

TADA3 Transcriptional adaptor 3

PRSS36 Protease, serine, 36

HELQ Helicase, POLQ-like

EMD Emerin

Clorf175 Chromosome 1 open reading frame 175

AEBP2

R3HDM1 R3H domain containing 1

SRPK1 Serine/arginine-rich splicing factor kinase 1

LEF1 Lymphoid enhancer-binding factor 1

MPHOSPH10 M-phase phosphoprotein 10

(U3 small nucleolar ribonucleoprote

PRDX1 Peroxiredoxin 1

MPP1 Membrane protein, palmitoylated 1,55kDa

CNOT2 CCR4-NOT transcription complex, subunit 2

GOLGA7 Golgin A7

WDR67 WD repeat domain 67

AAMP Angio-associated, migratory cell protein

KLHL9 Kelch-like 9 (Drosophila)
1.05E-02

Table 2 Genes ( $n=53$ ) with predicted DAS/DEU in All ASD vs. TD groups (FDR $\boldsymbol{P}<\mathbf{0 . 0 5 )}$ (Continued)

subjects included ILK Signaling, Natural Killer Cell Signaling, $\mathrm{FC} \gamma$ Receptor-mediated phagocytosis in macrophages and monocytes, and HMGB1 signaling (Figure 4, lower portion of cluster). The mTOR pathway was altered in 18 out of 30 ASD subjects (Figure 4). We performed this clustering analysis not so much to show clustering of pathways, since a number of these pathways contained common genes with DAS, but to identify clustering of subjects with particular sets of pathways being affected.

1.65E-02

2.17E-02

2.17E-02

2.47E-02

2.77E-02

$2.86 \mathrm{E}-02$

2.96E-02

$3.29 \mathrm{E}-02$

$3.29 \mathrm{E}-02$

3.29E-02

3.29E-02

3.29E-02

$3.53 \mathrm{E}-02$

3.53E-02

$3.61 \mathrm{E}-02$

4.10E-02

4.24E-02

\section{Discussion}

This study shows that differential alternative splicing may occur in selected genes in blood of 2-4-year-old boys with ASD compared to TD controls. There was an over-representation of DAS genes for pathways associated with the Nrf2-mediated oxidative stress response and superoxide radical degradation. In addition, there were genes with DAS from the Natural Killer cell, monocyte, NGF, and mTOR signaling pathways, which have been implicated in previous ASD studies [38,40,59-62]. An interesting result was that DAS in blood of ASD boys appeared to be more associated with normal cerebral volumes than with large cerebral volumes. Though the data are limited by small sample size and dependence of DAS predictions from exon arrays, they provide support for DAS occurring in blood as well as that already reported in brain [5], and will provide candidate genes for subsequent confirmatory studies. 


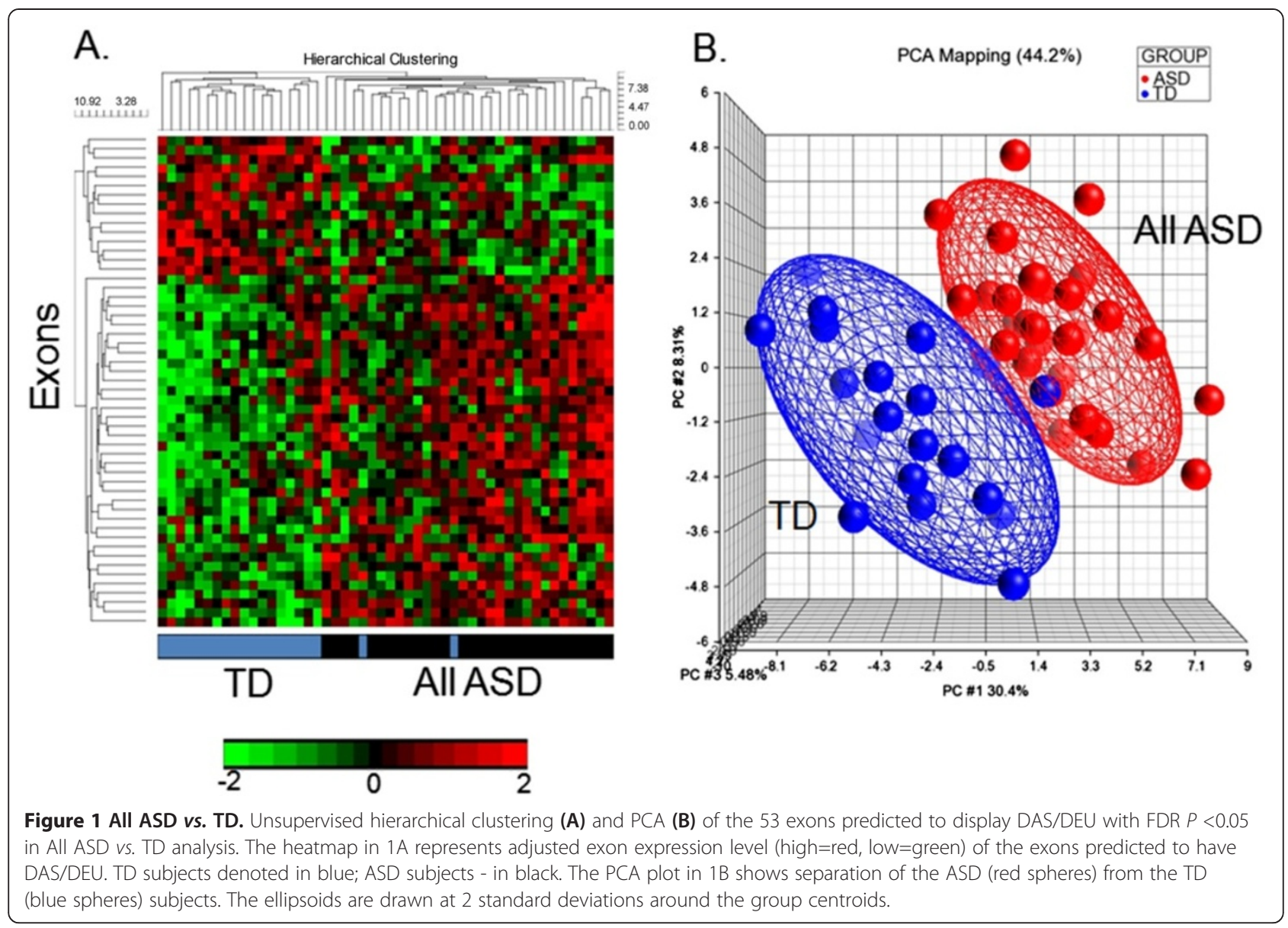

\section{Oxidative stress responses}

DAS was predicted for specific genes in the superoxide radical degradation and Nrf-2 mediated oxidative stress pathways which were significant for the ALL ASD versus TD comparison. SOD2 is a mitochondrial matrix protein that transforms toxic superoxide, a by-product of the mitochondrial electron transport chain, into hydrogen peroxide and diatomic oxygen. Mice without SOD2 die shortly after birth [63]. Catalase decomposes toxic hydrogen peroxide produced by SOD to water and oxygen. Peroxiredoxin 1 (PRDX1) catalyzes peroxide reduction of hydrogen peroxide, organic hydroperoxides, and peroxynitrite, and thus decreases oxidative stress in cells. The MGST3 gene encodes the enzyme Microsomal glutathione S-transferase 3 which demonstrates glutathione-dependent peroxidase activity towards lipid hydroperoxides. All of these genes are induced by reactive oxygen species (ROS). ROS cause the transcription factor Nrf2 to translocate from cytoplasm to the nucleus where $\mathrm{Nrf} 2$ binds anti-oxidant response elements (ARE) in promoters of Nrf2 target anti-oxidant genes including SOD2, CAT, PRDX1, and MGST3 to increase RNA expression [64].

There is some evidence of oxidative stress [65-68] and abnormal levels of superoxide and catalase in blood of ASD children [69-71]. There is also increased oxidative stress in
ASD brain and specific abnormalities related to glutathione and superoxide [67,72]. Moreover, mitochondrial abnormalities have been identified in blood of ASD subjects [9] that could contribute to ROS production and alterations of Nrf2 and SOD2 pathways identified here. Mitochondrial abnormalities are also found in brain [73]. Though oxidative stress may not be causal, the results of the current study support the possibility of DAS in specific oxidative stress genes in peripheral blood cells is associated with ASD. This association probably is not specific since evidence of oxidative stress is seen in other neurodevelopmental disorders and also occurs during normal function of the immune system.

\section{Regulators of alternative splicing}

A number of the genes predicted to have DAS in ASD either regulate splicing and/or are transcriptional regulators. Some of these genes included: SFPQ (splicing factor proline/glutamine rich), SRPK1 (serine/argininerich splicing factor kinase 1), SRSF11 (serine/argininerich splicing factor 11), SRSF2IP (splicing factor, arginine/serine-rich 2-interacting protein), FUS (fused in sarcoma), and LSM14A (SCD6 homolog A-yeast).

SFPQ , a DNA and RNA binding protein, is an essential pre-mRNA splicing factor required early in spliceosome 


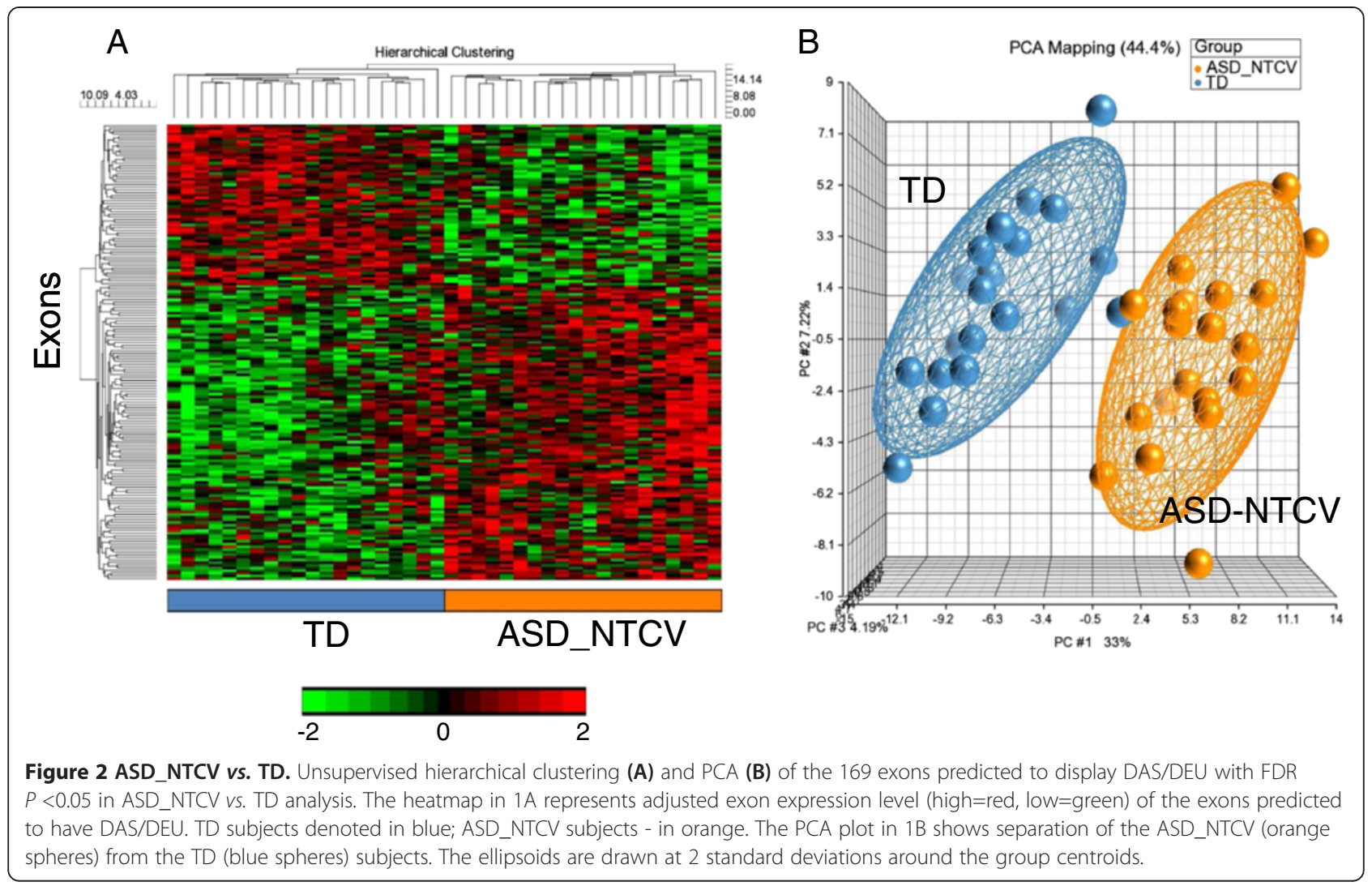

formation and for splicing catalytic step II. It binds to premRNA in the spliceosome $\mathrm{C}$ complex and regulates both alternative splicing and transcription. SFPQ has been associated with Alzheimer's disease [74] and plays a role in neuronal survival and differentiation during development [75].

SRPK1 regulates splicing, controlling the intranuclear distribution of splicing factors in interphase cells, and regulates splice site selection. Alternative splicing of this gene results in multiple transcript variants. In brain, SRPK1 is expressed in cortical and hippocampal pyramidal neurons, cortical and cerebellar granule cells, and Purkinje cell neurons, and regulates alternative splicing of glutamate receptor subunit 2 (GluR2) and tau protein [76].

The SRSF11 gene encodes a nuclear protein that contains an arginine/serine-rich region similar to segments found in other pre-mRNA splicing factors and also plays a role in pre-mRNA processing and splicing including the human telomerase protein [77]. The related SRSF2IP (SCAF11) is another pre-mRNA splicing factor showing differential alternative splicing in ASD in this study.

The Fus gene encodes a protein component of the heterogeneous nuclear ribonucleoprotein (hnRNP) complex which regulates pre-mRNA splicing and export of fully processed mRNA to cytoplasm. This protein belongs to the FET family of RNA-binding proteins which regulate gene expression and process mRNA/microRNA. Fus proteins are found in brain cytoplasmic inclusions of patients with fronto-temporal dementia, affect tau splicing, and Fus mutations have been associated with familial amyotrophic lateral sclerosis [78]. Fus protein decreases in cortex during development [79].

LSM14A is homologous to Sm-like (LSm) proteins which are members of the tri-snRNP (small nuclear ribonucleoprotein) particles that regulate pre-mRNA splicing. Mutations in snRNP proteins have been associated with neurodevelopmental disorders with ASD features, including Prader-Willi and Angelman Syndrome [80,81].

Though most of the above genes have not been directly implicated in ASD, they could affect differential alternative splicing of ASD susceptibility genes [82]. Moreover, alternative splicing appears to play a role in some known genetic causes of ASD. There is aberrant alternative splicing in single gene mutations associated with ASD (CADPS2, NLGN3, NLGN4X, NRXN1, and SHANK3). There is dysregulated splicing in some single gene disorders responsible for some forms of syndromic autism (tuberous sclerosis and neurofibromatosis); and still other genes associated with syndromic autisms encode proteins that can modulate alternative splicing (FMR1, MECP2, and SNRPN-Fragile X and Retts Syndrome) [82]. In addition, a recent study demonstrated differential expression of mRNA in brain between ASD and controls, which revealed enrichment of mRNAs involved in the process of alternative splicing [35]. 
Table 3 Genes ( $n=27$ ) with predicted DAS/DEU in ASD_LTCV vs. ASD_NTCV groups (FDR $P<0.05$ )

\begin{tabular}{|c|c|c|}
\hline $\begin{array}{l}\text { Gene } \\
\text { symbol }\end{array}$ & Gene title & $\begin{array}{l}\text { FDR } P \\
\text { (DAS) }\end{array}$ \\
\hline TMEM204 & Transmembrane protein 204 & $2.26 \mathrm{E}-05$ \\
\hline SRSF2IP & $\begin{array}{l}\text { Splicing factor, arginine/serine- } \\
\text { rich 2-interacting protein }\end{array}$ & 7.17E-05 \\
\hline PPP1R10 & $\begin{array}{l}\text { Protein phosphatase 1, regulatory } \\
\text { (inhibitor) subunit } 10\end{array}$ & 4.19E-04 \\
\hline ATXN7L3B & Ataxin 7-like 3B & $1.52 \mathrm{E}-03$ \\
\hline HPS1 & Hermansky-Pudlak syndrome 1 & $1.90 \mathrm{E}-03$ \\
\hline ANKRD44 & Ankyrin repeat domain 44 & $4.46 \mathrm{E}-03$ \\
\hline EXOG & $\begin{array}{l}\text { Endo/exonuclease }\left(5^{\prime}-3^{\prime}\right) \text {, } \\
\text { endonuclease G-like }\end{array}$ & $5.11 \mathrm{E}-03$ \\
\hline ZNF493 & Zinc finger protein 493 & $1.51 \mathrm{E}-02$ \\
\hline $\mathrm{DH} \times 29$ & DEAH (Asp-Glu-Ala-His) box polypeptide 29 & 1.57E-02 \\
\hline HOOK2 & Hook homolog 2 (Drosophila) & $2.02 \mathrm{E}-02$ \\
\hline IL12RB2 & Interleukin 12 receptor, beta 2 & 2.14E-02 \\
\hline BAT3 & HLA-B associated transcript 3 & $2.53 \mathrm{E}-02$ \\
\hline DVL3 & Dishevelled, dsh homolog 3 (Drosophila) & $2.53 \mathrm{E}-02$ \\
\hline RAB7A & RAB7A, member RAS oncogene family & $2.53 \mathrm{E}-02$ \\
\hline TNFRSF14 & $\begin{array}{l}\text { Tumor necrosis factor receptor } \\
\text { superfamily, member } 14\end{array}$ & $2.53 \mathrm{E}-02$ \\
\hline PPIP5K2 & $\begin{array}{l}\text { Diphosphoinositol pentakisphosphate } \\
\text { kinase } 2\end{array}$ & 2.67E-02 \\
\hline NDST1 & $\begin{array}{l}\text { N-deacetylase/N-sulfotransferase } \\
\text { (heparan glucosaminyl) } 1\end{array}$ & 3.26E-02 \\
\hline $\mathrm{DPH} 2$ & DPH2 homolog (S. cerevisiae) & 3.71E-02 \\
\hline PDP1 & $\begin{array}{l}\text { Pyruvate dehyrogenase phosphatase } \\
\text { catalytic subunit } 1\end{array}$ & 3.71E-02 \\
\hline TGFB111 & $\begin{array}{l}\text { Transforming growth factor beta } \\
1 \text { induced transcript } 1\end{array}$ & 4.14E-02 \\
\hline UBA6 & Ubiquitin-like modifier activating enzyme 6 & 4.41E-02 \\
\hline SLC38A5 & Solute carrier family 38, member 5 & $4.42 \mathrm{E}-02$ \\
\hline PLCD3 & Phospholipase C, delta 3 & 4.45E-02 \\
\hline COL15A1 & Collagen, type XV, alpha 1 & 4.47E-02 \\
\hline KDELR3 & $\begin{array}{l}\text { KDEL (Lys-Asp-Glu-Leu) endoplasmic } \\
\text { reticulum protein }\end{array}$ & 4.47E-02 \\
\hline $\mathrm{BIRC} 3$ & Baculoviral IAP repeat-containing 3 & 4.47E-02 \\
\hline ALOX15 & Arachidonate 15-lipoxygenase & 4.47E-02 \\
\hline
\end{tabular}

\section{Regulation of transcription, protein synthesis, and protein} degradation

The number two network for ASD_NTCV versus TD was Cellular Assembly, Function and Organization and RNA Post-Transcriptional Modification which had Ubiquitin $\mathrm{C}$ at its hub (Additional file 1: Figure S2). There were a number differentially alternatively spliced genes in our ASD analyses that functioned in regulating transcription, translation, and protein degradation at various levels.

\section{Transcription}

There were many genes with predicted DAS in ASD versus TD that regulated transcription including POLR2B (polymerase (RNA) II (DNA directed) polypeptide B, $140 \mathrm{kDa})$. POLR2B encodes the second largest subunit of RNA polymerase II, the polymerase responsible for synthesizing messenger RNA in eukaryotes. This subunit, in combination with at least two other polymerase subunits, forms a structure within the polymerase that maintains contact in the active site of the enzyme between the DNA template and the newly synthesized RNA, playing a key role in transcription as well as alternative splicing. Though not implicated in ASD, in Alzheimer brain the hyperphosphorylation of RNA polymerase II and decreases of RNA levels precede neurofibrillary tangle formation [83].

MED12 (mediator complex subunit 12) is a component of the Mediator complex, a co-activator involved in the regulated transcription of nearly all RNA polymerase II-dependent genes. This subunit may regulate transcription of targets of the Wnt signaling pathway and $\mathrm{SHH}$ signaling pathway relevant for neurodevelopment and intellectual disability syndromes [84-86].

Another DAS gene was TADA3 (Transcriptional Adaptor 3) which enhances the initiation rate of RNA polymerase II-mediated gene transcription by interacting functionally with the general transcription machinery bound at the basal promoter (see below). Related genes included MLL3, a histone methyl transferease, which is a co-activator complex of nuclear receptors, involved in transcriptional co-activation. The gene is essential for normal embryogenesis and cell cycle progression [87]. Another related DAS gene is ASH2L (ash2 (absent, small, or homeotic)-like (Drosophila) is part of the MLL1/MLL2 histone methyltransferase (HMT) complex. It is involved in methylation/ demethylation and functions as a transcriptional activator and may play a role in chromosome demarcation [88].

There were also several transcription factors predicted to have DAS in ASD including STAT4, CNOT2, and NPAS2 and TCF1 (Transcription Factor 19). NPAS2, a member of the basic helix-loop-helix (bHLH)-PAS family of transcription factors, regulates transcription of proteins involved in specific types of memory, several proteins (PER1) that are part of the molecular clock in the mammalian forebrain, and has been implicated in ASD [89]. STAT4 (signal transducer and activator of transcription 4) is essential for mediating responses to IL12 in lymphocytes, and regulating the differentiation of T helper cells. STAT4 regulates perforin expression in cytotoxic T cells and Natural Killer cells [90], the latter cells having been shown to have altered cytotoxic/perforin functions in ASD [59].

There is evidence for coupling of transcription and splicing, with faster rates of transcription being associated 


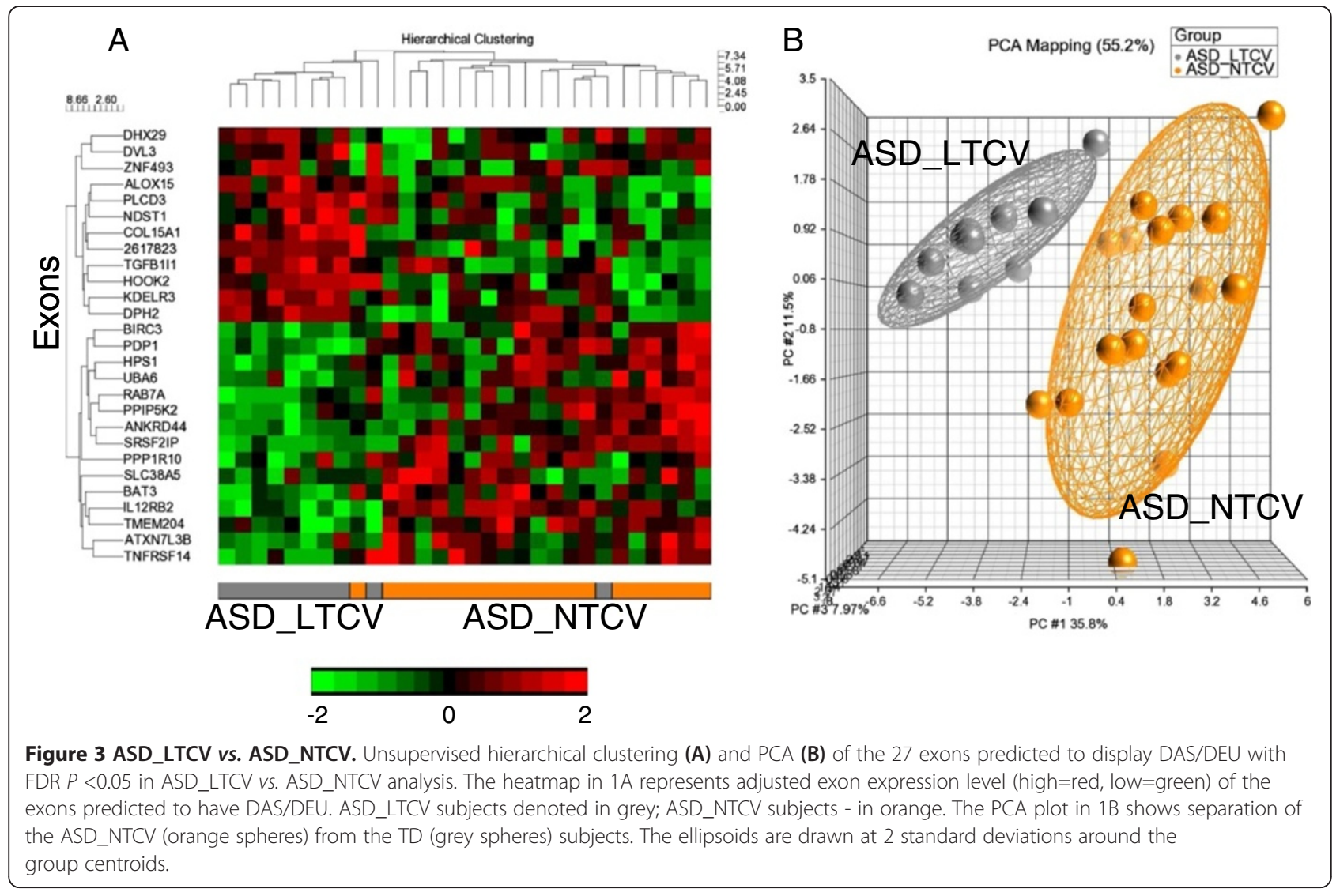

with exon skipping $[91,92]$. Thus DAS in genes affecting transcription could result in alterations of DAS in a number of targets.

\section{Translation}

There were also many DAS genes involved in regulating translation including: PIK3C3 (in mTOR pathway); PPP1R9B ( protein phosphatase 1, regulatory (inhibitor) subunit 9B); FXR1 (fragile X mental retardation, autosomal homolog 1); PPP2R2A (protein phosphatase 2, regulatory subunit B, alpha-mTOR); ELP2 (elongation protein 2 homolog-yeast); EIF2AK1 (eurkaryotic translation initiation factor 2-alpha kinase 1); MRPL40 (mitochondrial ribosomal protein L 40); TARS2 (threonyl-tRNA synthetase 2, mitochondrial); YARS (tyrosyl -tRNA synthetase); and EIF2C3 (eukaryotic translation initiation factor 2C, 3). These many genes involved in translation relate directly and indirectly to PI3K/AKT/mTOR pathways, a result which was also supported by our sub-analysis on the pathways affected in each ASD subject discussed below (see section on Pathways previously implicated in ASD).

\section{Ubiquitination and protein degradation}

Several genes with predicted DAS in ASD were related to ubiquitin pathways, and ubiquitin was a hub in several regulated networks (Additional file 1: Figure S2).
These genes included USP48 (ubiquitin specific peptidase 48), UBA6 (ubiquitin-like modifier activating enzyme 6), BIRC3 (baculoviral IAP repeat-containing 3), and DnaJC17 (DNAJ (Hsp40) homolog, subfamily C, member 17). BIRC3 Acts as an E3 ubiquitin-protein ligase regulating NF-kappa-B signaling and regulates both canonical and non-canonical NF-kappa-B signaling. The target proteins for its E3 ubiquitin-protein ligase activity include: RIPK1, RIPK2, RIPK3, RIPK4, CASP3, CASP7, CASP8, TRAF1, and BCL10. Ubiqutin pathways have been implicated in autism for some time and are specifically linked to autism associated with 15q11-q13 chromosome deletions $[93,94]$.

\section{Genes implicated in previous autism studies - GWAS and RNA expression in brain}

Of the genes predicted to be alternatively spliced in ASD versus TD boys in this study, some have been implicated in previous genetic studies of ASD including Gelsolin (GSN), LRPPRC (leucine-rich PPR-motif containing), BIN1 (bridging integrator 1), MED12 (mediator complex subunit 12), NPAS2 (neuronal PAS domain protein 2), SYNE1 (spectrin repeat containing, nuclear envelope 1), and TBL1XR1 (transducin (beta)-like X-linked receptor 1) $[73,89,95-97]$. Thus, there is overlap of genes implicated in 


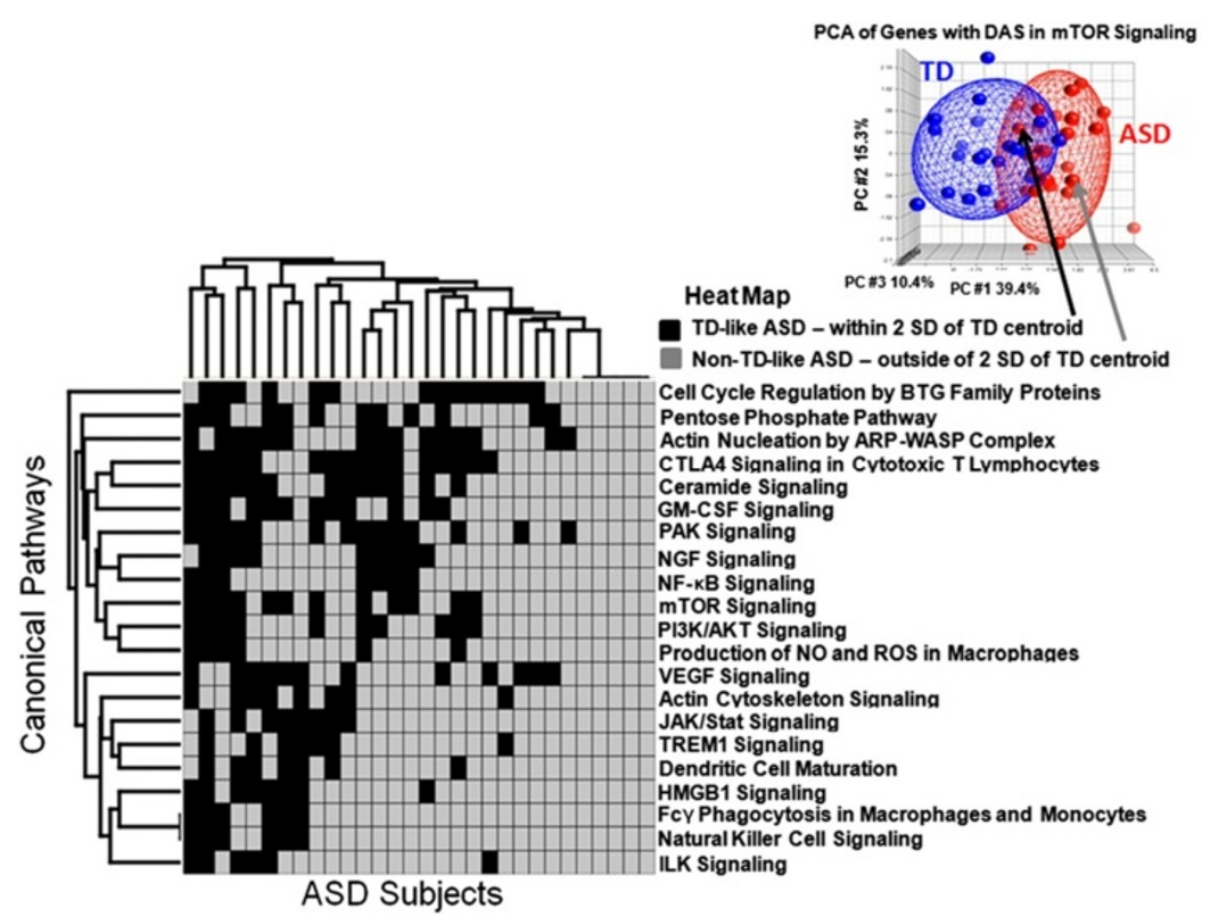

Figure 4 Individual-subject level analysis. Hierarchical clustering of ASD subjects and significant pathways $(P<0.05)$. Each ASD subject in each of the significant pathways was scored as either TD-like, if its PCA position on the PCA plot for the genes with DAS/DEU in the particular pathway was within 2 SD of the TD centroid (within the TD ellipsoid); or as non-TD-like, if its PCA position on the first three PCA components space was outside 2 SD of the TD centroid (outside of the TD ellipsoid). An example of the scoring scheme - in the upper right-hand corner - is presented for the mTOR signaling pathway.

previous genetic ASD studies and the findings in this study of DAS in ASD.

Gelsolin has been implicated in previous genetic studies of ASD [95], has been reported to be differentially spliced in ASD compared to TD brain [5], and is predicted to be alternatively spliced in the ALL ASD versus TD analysis and the ASD_NTCV versus TD analysis in this study. Gelsolin protein binds the 'plus' ends of actin monomers and filaments to prevent monomer exchange, and modulates assembly and disassembly of actin filaments. Mutations of this gene cause familial amyloidosis Finnish type (FAF) [98]. Multiple transcript variants encoding several different isoforms have been found. Gelsolin levels increase in brain during development, and are higher in children with Down's syndrome [99]. In brain gelsolin has many roles including modulating NMDA receptors, altering dendritic spines, being highly expressed by oligodendrocytes, and modulating amyloidosis [100-102].

The LPPRC gene has also been implicated in previous ASD genetic studies [73,95]. In the nucleus it binds HNRPA1-associated poly(A) mRNAs and is part of nmRNP complexes at late stages of mRNA maturation which are associated with nuclear mRNA export. In mitochondria the protein binds to poly(A) mRNA and stabilizes mitochondrially encoded cytochrome c oxidase
(COX) subunits. It cooperates with PPARGC1A to regulate certain mitochondrially encoded genes and gluconeogenic genes and may regulate docking of PPARGC1A to transcription factors and regulates transcription of the multidrug-related genes MDR1 and MVP. The LPPRC proteinis reduced over two-fold in ASD compared to control brain [73]. The LPPRC protein directly binds Neurofibromin 1, mutations of which can be associated with ASD [103].

MED12 (see above) has also been implicated as a genetic susceptibility ASD gene [95]. A novel X-linked disorder with developmental delay and autistic features with duplication of Xq12-q13.3 involves the MED12 gene [104]. MED12 is linked to the sonic hedgehog pathway and mutations in the gene are associated with mental retardation and autism like features [86]. Med12dependent recruitment of the Mediator complex with Sox10 promotes terminal differentiation of myelinating glia [105]. MED12 plays a key role in forming the hindbrain during development [84].

TBL1XR1 (transducin (beta)-like 1X-linked receptor 1 trascription regulator, beta-catenin binding) has also been implicated in ASD. It localizes to the histone deacetylase complex and interacts with HDAC3 and RNA polymerase II, playing a key role in regulating 
transcription. This gene is one of six newly identified genes that have recurrent mutations that are associated with ASD [106]. This gene also regulates the beta catenin Wnt signaling pathway which has also been implicated in ASD $[97,107]$.

Of the ASD genes found to demonstrate DAS in blood in this study, several of these have been reported to also be differentially alternatively spliced in ASD brain. These include: GSN; CLTB (clathrin, light chain); OS9 (osteosarcoma amplified 9, endoplasmic reticulum lectin); BIN1; CHPT1 (choline phosphotransferase 1); LSM14A (SCD6 homolog A); MINK1 (misshapen-like kinase 1); and SYNE1 [5]. Though the function of these genes may be different in blood and brain [108], and even though the exons involved are different as expected since alternative splicing is highly tissue-specific, DAS of the same genes in blood and brain represents an independent line of evidence for these genes being affected by DAS/DEU in different cohorts and tissues in ASD.

\section{Pathways previously implicated in ASD: subject-level pathways affected by DAS in ASD}

The pathway analysis summarized in Figure 4 was based on the 21 pathways that were significantly different between ALL ASD and TD and which were derived from 477 exons predicted to participate in differential alternative splicing as well as have a significant difference of exon expression between ASD and TD. The unique feature of this analysis was that each pathway was scored as TD-like or non-TD like for each individual. The data show that no pathway is associated with all ASD children, and only five of 30 ASD children had alterations in all of the pathways, whereas the remainder had alterations in different subsets of pathways. The finding of alterations in the Natural Killer Cell and NGF pathways in the majority of ASD children confirms our and other previous studies [59-61]. Alterations in genes in monocyte-related pathways in most ASD children could relate to reported differential monocyte responses to TLR ligands in children with ASD [62], to microglia (brain macrophages) activation in ASD brain [22,109] and microglial genes being over-expressed in ASD brain [5].

Our pathway analyses per individual showed that $60 \%$ of the ASD children in this study had predicted DAS abnormalities of mTOR pathways (Figure 4). This is notable since mutations of single genes often associated with ASD clinical features also have aberrant mTOR signaling including Fragile $\mathrm{X}$, tuberous sclerosis, PTEN, and neurofibromatosis $[38,40]$. Thus these data point to possible abnormalities of mTOR pathways in a subgroup of 'idiopathic' ASD which may have clinical relevance since mTOR inhibitors like rapamycin can modulate these pathways [110]. Though there are 21 pathways shared between all of the ASD subjects, and though some subjects share some common pathways, only five subjects share the same pathways [3]. Thus, a variety of different combinations of pathways appear to be associated with idiopathic ASD. This would be consistent with the many known genetic causes of ASD which are also associated with many different pathways. However, it also shows some convergence on similar biological processes at least for subgroups of ASD subjects as discussed above [111].

Our novel pathway analysis supports previously published data on alterations in pathways in ASD, such as oxidative stress [61], mTOR [38], Natural Killer cells $[59,60]$, NGF, and monocyte pathways [112], as well as activation of microglia (macrophages in the periphery) $[22,109]$. However, this is the first study to suggest DAS/ DEU occurs in these pathways and thus confirmation is needed in a future independent cohort. We performed this sub-analysis to address the heterogeneity in ASD at the level of each individual ASD subject. Though every gene/pathway may not be reproduced, we propose this as a plausible approach to investigate ASD heterogeneity and identify ASD subgroups at the transcriptome level.

\section{Differential alternative splicing in ASD with large TCV}

There was one gene with DAS in ASD_LTCV when compared to TD: membralin (C19orf6). Membralin is a highly conserved transmembrane protein, which does not share significant sequence homology with other human genes, only membralins of other species. It is expressed in the central nervous system [113] and is associated with ovarian carcinoma [114]. Membralin interacts with UBC, TMEM173, and ARSE proteins (www.GeneCards.org; www.string-db.org). UBC, involved in protein degradation and ubiquitinization, was a convergence node of direct interactions with genes with DAS in All ASD versus TD and the LTCV versus NTCV ASD comparisons.

Though little is known about membralin function, some of its interacting partners belong to proteins implicated in ASD. A rare CNV in the AGMO (TMEM195) gene has been identified with autism in AGRE and NIMH cohorts [95,115]. In addition, a number of ubiquitin-related genes have also been implicated in ASD, and membralin interacts with the ubiquitin $C$ (UBC) protein [95].

\section{Effect of total brain volume}

One surprising result of the study was that though over 100 genes were predicted to demonstrate DAS for the ASD_NTCV versus TD comparison, only one gene was predicted to show DAS for the ASD_LTCV versus TD comparison (membralin). This could be interpreted to mean that DAS/DEU is associated more with the pathophysiology of ASD with normal brain volumes rather than ASD with large brain volumes. If this is the case, 
there is no ready explanation for this finding though it is consistent with a different pathophysiology of the ASD_LTCV and ASD_NTCV subgroups. There were 27 genes that demonstrated DAS in the ASD_NTCV versus ASD_LTCV comparison, which associated with many pathways including IL12 signaling in macrophages, Inositol Pyrophosphates Biosynthesis, synaptic long-term potentiation, PKA signaling, Dopamine-DARPP32 Feedback in cAMP Signaling, and others. Given that only one gene differed in the ASD_LTCV to TD comparison, these differences are likely driven by the ASD_NTCV group. The data would suggest that future genetic, imaging, biomarker, and behavioral studies should consider head size for defining clinical ASD subgroups.

\section{Limitations}

Cause and effect cannot be determined from this study. Since blood samples were used, it is not known to what extent the observed changes reflect changes in the brain. It is likely that many of these changes reflect differences in the peripheral immune system of ASD and are associated with the immune and autoimmune dysregulation observed in some ASD subjects [112].

The sample size is small and though multiple comparison adjustments were made, the problem of false positives can only be addressed by replication in future studies. CNVs, SNPs, and other processes could affect the exon usage measured in this study which would not represent differences of alternative splicing. Therefore, alternative splicing predicted using exon arrays in this study will require confirmation using other approaches that directly measure expression of alternatively spliced variants of single genes. The current study provides one source for determining which genes might be evaluated in future studies.

\section{Conclusions}

The data in this study suggests that DAS occurs in blood of 2-4-year-old boys with ASD compared to TD controls. Different ASD subgroups based on TCV exhibited specific DAS. These findings are preliminary and need to be replicated in independent cohorts.

\section{Additional files}

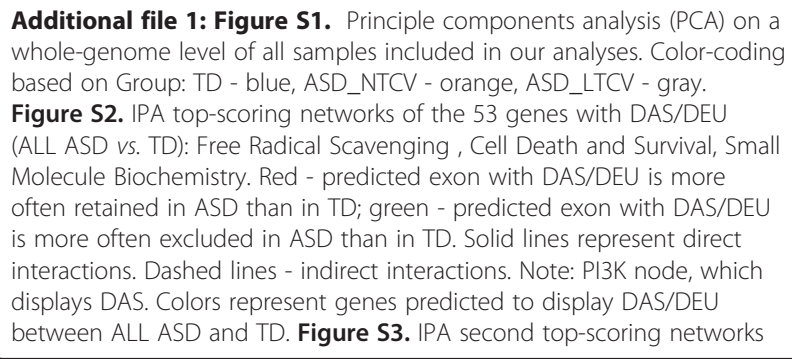

of the 27 genes with DAS/DEU in ASD_LTCV vs. ASD_NTCV: Cellular Assembly and Organization, Cellular Function and Maintenance, RNA Post-Transcriptional Modification. Note: UBC convergence hub of direct interactions. Colors represent genes predicted to display DAS/DEU between ASD_LTCV and ASD_NTCV and TD. Red - predicted exon with DAS/DEU is more often retained in ASD_LTCV than in ASD_NTCV; green predicted exon with DAS/DEU is more often excluded in ASD_LTCV than in ASD_NTCV. Solid lines represent direct interactions. Dashed lines indirect interactions.

Additional file 2: Table S1. Genes $(n=53)$ with predicted DAS/DEU in ALL ASD vs. TD groups (FDR $P<0.05$ ). Table S2. Genes $(n=169)$ with predicted DAS/DEU in ASD_NTCV vs. TD groups (FDR $P<0.05$ ). Table S3. Genes $(n=27)$ with predicted DAS/DEU in ASD_LTCV vs. ASD_NTCV groups (FDR $P<0.05)$. Table S4. Genes $(n=477)$ with predicted DAS/DEU in sub-analysis of ALL ASD vs. TD Groups for individual subject-level pathway analysis. Table S5. Functional analysis using IPA of the 477 DAS genes in the sub-analysis of ALL ASD compared to TD (see Table S4) revealed that 21 canonical pathways were over-represented $(P<0.05)$. These 21 pathways and the genes with DAS in each pathway are listed below. These 21 pathways were used for the analysis shown in Figure 4 .

\section{Abbreviations}

ASD: Autism spectrum disorders; DAS: Differential alternative splicing; DEU: Differential exon usage; LTCV: Large total cerebral volume;

NTCV: Normal total cerebral volume; TD: Typically developing.

\section{Competing interests}

The authors declare that they have no competing interests.

\section{Authors' contributions}

BS and FRS devised the study. CWN, MDS, SR, and DGA selected participants, oversaw diagnostic evaluations, and directed MRI studies and analyses. BS and $Y T$ performed the statistical analyses. BS and FRS wrote the manuscript and all authors participated in reviewing and editing the manuscript.

\section{Acknowledgements}

The study was supported by the MIND Institute (FRS), the UC Davis Children's Miracle Network (FRS and BS), and by ARRA funding 1R01MH089626 to DGA. Dr. Yingfang Tian was supported by Science Technology Foundation of Shaanxi Province, PR China (2012K16-03-05).

\section{Author details}

${ }^{1}$ MIND Institute, University of California at Davis, Sacramento, CA 95817, USA. 2Department of Neurology, University of California at Davis, Sacramento, CA 95817, USA. ${ }^{3}$ Department of Psychiatry and Behavioral Sciences, University of California at Davis, Sacramento, CA 95817, USA. ${ }^{4}$ College of Life Sciences, Shaanxi Normal University, Xi'an 710062, China. ${ }^{5}$ MIND Institute Research Wet Labs, University of California at Davis, Room 2417, 2805 50th Street,

Sacramento, CA 95817, USA.

Received: 4 June 2013 Accepted: 6 August 2013

Published: 4 September 2013

\section{References}

1. American Psychiatric Association: Diagnostic and Statistical Manual of Mental Disorders, Fourth Edition, Text Revision (DSM-IV-TR). Arlington, VA: American Psychiatric Association; 2000.

2. Geschwind DH: Genetics of autism spectrum disorders. Trends Cogn Sci 2011, 15:409-416

3. Bill BR, Geschwind DH: Genetic advances in autism: heterogeneity and convergence on shared pathways. Curr Opin Genet Dev 2009, 19:271-278.

4. Carter M, Scherer S: Autism spectrum disorder in the genetics clinic: a review. Clin Genet 2013, 83:399-407.

5. Voineagu I, Wang X, Johnston P, Lowe JK, Tian Y, Horvath S, Mill J, Cantor RM, Blencowe BJ, Geschwind DH: Transcriptomic analysis of autistic brain reveals convergent molecular pathology. Nature 2011, 474:380-384.

6. Napolioni $V$, Persico AM, Porcelli V, Palmieri L: The mitochondrial aspartate/glutamate carrier AGC1 and calcium homeostasis: physiological links and abnormalities in autism. Mol Neurobiol 2011, 44:83-92. 
7. Palmieri L, Persico AM: Mitochondrial dysfunction in autism spectrum disorders: cause or effect? Biochim Biophys Acta 2010, 1797:1130-1137.

8. Palmieri L, Papaleo V, Porcelli V, Scarcia P, Gaita L, Sacco R, Hager J, Rousseau F, Curatolo P, Manzi B, Militerni R, Bravaccio C, Trillo S, Schneider C, Melmed R, Elia M, Lenti C, Saccani M, Pascucci T, Puglisi-Allegra S, Reichelt KL, Persico AM: Altered calcium homeostasis in autism-spectrum disorders: evidence from biochemical and genetic studies of the mitochondrial aspartate/glutamate carrier AGC1. Mol Psychiatry 2010, 15:38-52.

9. Giulivi C, Zhang YF, Omanska-Klusek A, Ross-Inta C, Wong S, Hertz-Picciotto I, Tassone F, Pessah IN: Mitochondrial dysfunction in autism. JAMA 2010, 304:2389-2396

10. Rossignol DA, Frye RE: Mitochondrial dysfunction in autism spectrum disorders: a systematic review and meta-analysis. Mol Psychiatry 2012, 17:290-314

11. Frye RE, Rossignol DA: Mitochondrial dysfunction can connect the diverse medical symptoms associated with autism spectrum disorders. Pediatr Res 2011, 69:41R-47R.

12. Jaresova I, Rozkova D, Spisek R, Janda A, Brazova J, Sediva A: Kinetics of Toll-like receptor-4 splice variants expression in lipopolysaccharidestimulated antigen presenting cells of healthy donors and patients with cystic fibrosis. Microbes Infect 2007, 9:1359-1367.

13. Li R, Rosendahl A, Brodin G, Cheng AM, Ahgren A, Sundquist C, Kulkarni S, Pawson T, Heldin CH, Heuchel RL: Deletion of exon I of SMAD7 in mice results in altered $B$ cell responses. J Immuno/ 2006, 176:6777-6784.

14. Chisa JL, Burke DT: Mammalian mRNA splice-isoform selection is tightly controlled. Genetics 2007, 175:1079-1087.

15. Simarro M, Mauger D, Rhee K, Pujana MA, Kedersha NL, Yamasaki S, Cusick ME, Vidal M, Garcia-Blanco MA, Anderson P: Fas-activated serine/threonine phosphoprotein (FAST) is a regulator of alternative splicing. Proc Natl Acad Sci U S A 2007, 104:11370-11375.

16. Pleiss JA, Whitworth GB, Bergkessel M, Guthrie C: Rapid, transcript-specific changes in splicing in response to environmental stress. Mol Cell 2007, 27:928-937.

17. Takai K, Sakamoto S, Sakai T, Yasunaga J, Komatsu K, Matsuoka M: A potential link between alternative splicing of the NBS1 gene and DNA damage/environmental stress. Radiat Res 2008, 170:33-40.

18. Munoz MJ, Perez Santangelo MS, Paronetto MP, de la Mata M, Pelisch F, Boireau S, Glover-Cutter K, Ben-Dov C, Blaustein M, Lozano JJ, Bird G, Bentley D, Bertrand $E$, Kornblihtt AR: DNA damage regulates alternative splicing through inhibition of RNA polymerase II elongation. Cell 2009, 137:708-720.

19. Kurokawa K, Kuwano Y, Tominaga K, Kawai T, Katsuura S, Yamagishi N, Satake Y, Kajita K, Tanahashi T, Rokutan K: Brief naturalistic stress induces an alternative splice variant of SMG-1 lacking exon 63 in peripheral leukocytes. Neurosci Lett 2010, 484:128-132.

20. Priller J, Flugel A, Wehner T, Boentert M, Haas CA, Prinz M, Fernandez-Klett F, Prass K, Bechmann I, de Boer BA, Frotscher M, Kreutzberg GW, Persons DA, Dirnagl U: Targeting gene-modified hematopoietic cells to the central nervous system: use of green fluorescent protein uncovers microglial engraftment. Nat Med 2001, 7:1356-1361.

21. Simard AR, Rivest $\mathrm{S}$ : Bone marrow stem cells have the ability to populate the entire central nervous system into fully differentiated parenchymal microglia. FASEB J 2004, 18:998-1000.

22. Morgan JT, Chana G, Pardo CA, Achim C, Semendeferi K, Buckwalter J, Courchesne E, Everall IP: Microglial activation and increased microglial density observed in the dorsolateral prefrontal cortex in autism. Biol Psychiatry 2010, 68:368-376.

23. Careaga M, Van de Water J, Ashwood P: Immune dysfunction in autism: a pathway to treatment. Neurotherapeutics 2010, 7:283-292.

24. Wills S, Cabanlit M, Bennett J, Ashwood P, Amaral D, Van de Water J: Autoantibodies in autism spectrum disorders (ASD). Ann NY Acad Sci 2007, 1107:79-91.

25. Fatemi SH, Earle J, Kanodia R, Kist D, Emamian ES, Patterson PH, Shi L Sidwell R: Prenatal viral infection leads to pyramidal cell atrophy and macrocephaly in adulthood: implications for genesis of autism and schizophrenia. Cell Mol Neurobiol 2002, 22:25-33.

26. Ashwood $\mathrm{P}$, Wills $S$, Van de Water J: The immune response in autism: a new frontier for autism research. J Leukoc Biol 2006, 80:1-15.
27. Molina-Holgado E, Molina-Holgado F: Mending the broken brain: neuroimmune interactions in neurogenesis. J Neurochem 2010, 114:1277-1290.

28. Ziemssen T, Kern S: Psychoneuroimmunology-cross-talk between the immune and nervous systems. J Neurol 2007, Suppl 2:II/8-II/11.

29. Courchesne E, Karns CM, Davis HR, Ziccardi R, Carper RA, Tique ZD, Chisum HJ, Moses P, Pierce K, Lord C, Lincoln AJ, Pizzo S, Schreibman L, Haas RH, Akshoomoff NA, Courchesne RY: Unusual brain growth patterns in early life in patients with autistic disorder: an MRI study. Neurology 2001, 57:245-254

30. Nordahl CW, Lange N, Li DD, Barnett LA, Lee A, Buonocore MH, Simon TJ, Rogers S, Ozonoff S, Amaral DG: Brain enlargement is associated with regression in preschool-age boys with autism spectrum disorders. Proc Natl Acad Sci U S A 2011, 108:20195-20200.

31. Hazlett HC, Poe M, Gerig G, Smith RG, Provenzale J, Ross A, Gilmore J, Piven $\mathrm{J}$ : Magnetic resonance imaging and head circumference study of brain size in autism: birth through age 2 years. Arch Gen Psychiatry 2005, 62:1366-1376

32. Schumann CM, Bloss CS, Barnes CC, Wideman GM, Carper RA, Akshoomoff N, Pierce K, Hagler D, Schork N, Lord C, Courchesne E: Longitudinal magnetic resonance imaging study of cortical development through early childhood in autism. J Neurosci 2010, 30:4419-4427.

33. Fombonne E, Roge B, Claverie J, Courty S, Fremolle J: Microcephaly and macrocephaly in autism. J Autism Dev Disord 1999, 29:113-119.

34. Lainhart JE, Bigler ED, Bocian M, Coon H, Dinh E, Dawson G, Deutsch CK Dunn M, Estes A, Tager-Flusberg H, Folstein S, Hepburn S, Hyman S, McMahon W, Minshew N, Munson J, Osann K, Ozonoff S, Rodier P, Rogers S, Sigman M, Spence MA, Stodgell CJ, Volkmar F: Head circumference and height in autism: a study by the Collaborative Program of Excellence in Autism. Am J Med Genet A 2006, 140:2257-2274.

35. Raznahan A, Wallace GL, Antezana L, Greenstein D, Lenroot R, Thurm A, Gozzi M, Spence S, Martin A, Swedo SE, Giedd JN: Compared to what? Early brain overgrowth in autism and the perils of population norms. Biol Psychiatry 2013. doi:10.1016/j.biopsych.2013.03.022.

36. Chaste P, Klei L, Sanders SJ, Murtha MT, Hus V, Lowe JK, Willsey AJ, MorenoDe-Luca D, Yu TW, Fombonne E, Geschwind D, Grice DE, Ledbetter DH, Lord C, Mane SM, Lese Martin C, Martin DM, Morrow EM, Walsh CA, Sutcliffe JS, State MW, Devlin B, Cook EH Jr, Kim SJ: Adjusting Head Circumference for Covariates in Autism: Clinical Correlates of a Highly Heritable Continuous Trait. Biol Psychiatry 2013. doi:10.1016/j.biopsych.2013.04.018.

37. Zhou J, Parada LF: PTEN signaling in autism spectrum disorders. Curr Opin Neurobiol 2012, 22:873-879.

38. Kelleher RJ, Bear MF: The autistic neuron: troubled translation? Cell 2008, 135:401-406.

39. Butler MG, Dasouki MJ, Zhou XP, Talebizadeh Z, Brown M, Takahashi TN, Miles JH, Wang CH, Stratton R, Pilarski R, Eng C: Subset of individuals with autism spectrum disorders and extreme macrocephaly associated with germline PTEN tumour suppressor gene mutations. J Med Genet 2005, 42:318-321.

40. Gipson TT, Johnston MV: Plasticity and mTOR: towards restoration of impaired synaptic plasticity in mTOR-related neurogenetic disorders. Neural Plast 2012, 2012:486402.

41. Romaniello R, Tonelli A, Arrigoni F, Baschirotto C, Triulzi F, Bresolin N, Bassi MT, Borgatti R: A novel mutation in the beta-tubulin gene TUBB2B associated with complex malformation of cortical development and deficits in axonal guidance. Dev Med Child Neurol 2012, 54:765-769.

42. Edery P, Alix E, Clerget-Darpoux F, Leutenegger AL: [Extreme microcephaly and growth retardation caused by mutations in a non-coding RNA component of the minor spliceosome]. Med Sci (Paris) 2012, 28:130-133.

43. Brunk K, Vernay B, Griffith E, Reynolds NL, Strutt D, Ingham PW, Jackson AP. Microcephalin coordinates mitosis in the syncytial Drosophila embryo. J Cell Sci 2007, 120:3578-3588.

44. Varon R, Dutrannoy V, Weikert G, Tanzarella C, Antoccia A, Stockl L, Spadoni E, Kruger LA, di Masi A, Sperling K, Digweed M, Maraschio P: Mild Nijmegen breakage syndrome phenotype due to alternative splicing. Hum $\mathrm{Mol}$ Genet 2006, 15:679-689.

45. Anthony K, Gallo JM: Aberrant RNA processing events in neurological disorders. Brain Res 2010, 1338:67-77.

46. Caceres JF, Kornblihtt AR: Alternative splicing: multiple control mechanisms and involvement in human disease. Trends Genet 2002, 18:186-193. 
47. Clark TA, Schweitzer AC, Chen TX, Staples MK, Lu G, Wang H, Williams A, Blume JE: Discovery of tissue-specific exons using comprehensive human exon microarrays. Genome Biol 2007, 8:R64.

48. Glatt SJ, Cohen OS, Faraone SV, Tsuang MT: Dysfunctional gene splicing as a potential contributor to neuropsychiatric disorders. Am J Med Genet B Neuropsychiatr Genet 2011, 156B:382-392.

49. Lord C, Risi S, Lambrecht L, Cook E, Leventhal B, DiLavore P, Pickles A, Rutter $M$ : The autism diagnostic observation schedule-generic: a standard measure of social and communication deficits associated with the spectrum of autism. J Autism Dev Disord 2000, 30:205-223.

50. Lord C, Rutter M, Le Couteur A: Autism Diagnostic Interview-Revised: a revised version of a diagnostic interview for caregivers of individuals with possible pervasive developmental disorders. J Autism Dev Disord 1994, 24:659-685.

51. Gotham K, Pickles A, Lord C: Standardizing ADOS scores for a measure of severity in autism spectrum disorders. J Autism Dev Disord 2009, 39:693-705.

52. Mullen EM: Mullen Scales of Early Learning. Pines, MN: American Guidance Service; 1995.

53. Rutter M, Bailey A, Lord C (Eds): The Social Communication Questionnaire. Los Angeles, CA: Western Psychological Services; 2003.

54. Ashwood P, Krakowiak P, Hertz-Picciotto I, Hansen R, Pessah IN, Van de Water J: Associations of impaired behaviors with elevated plasma chemokines in autism spectrum disorders. J Neuroimmunol 2011, 232:196-199.

55. Tian $Y$, Liao $I H$, Gunther JR, Liu D, Ander BP, Stamova BS, Lit L, Jickling GC, Xu H, Zhan X, Sharp FR: GABA- and acetylcholine-related gene expression in blood correlate with tic severity and microarray evidence for alternative splicing in Tourette syndrome: a pilot study. Brain Res 2011, 14:14

56. Tamhane A, Dunlop D: Statistics and Data Analysis: From Elementary to Intermediate. Upper Saddle River, NJ: Prentice Hall; 2000.

57. Eisenhart $C$ : The assumptions underlying the analysis of variance. Biometrics 1947, 3:20

58. Reiner A, Yekutieli D, Benjamini Y: Identifying differentially expressed genes using false discovery rate controlling procedures. Bioinformatics 2003, 19:368-375

59. Enstrom AM, Lit L, Onore CE, Gregg JP, Hansen RL, Pessah IN, Hertz-Picciotto I, Van de Water JA, Sharp FR, Ashwood P: Altered gene expression and function of peripheral blood natural killer cells in children with autism. Brain Behav Immun 2009, 23:124-133.

60. Gregg JP, Lit L, Baron CA, Hertz-Picciotto I, Walker W, Davis RA, Croen LA, Ozonoff S, Hansen R, Pessah IN, Sharp FR: Gene expression changes in children with autism. Genomics 2008, 91:22-29.

61. Lu AT, Yoon J, Geschwind DH, Cantor RM: QTL replication and targeted association highlight the nerve growth factor gene for nonverbal communication deficits in autism spectrum disorders. Mol Psychiatry 2013, 18:226-235.

62. Enstrom AM, Onore CE, Van de Water JA, Ashwood P: Differential monocyte responses to TLR ligands in children with autism spectrum disorders. Brain Behav Immun 2010, 24:64-71.

63. Li Y, Huang TT, Carlson EJ, Melov S, Ursell PC, Olson JL, Noble LJ, Yoshimura MP, Berger C, Chan PH, Wallace DC, Epstein CJ: Dilated cardiomyopathy and neonatal lethality in mutant mice lacking manganese superoxide dismutase. Nat Genet 1995, 11:376-381.

64. Zhang M, An C, Gao Y, Leak RK, Chen J, Zhang F: Emerging roles of Nrf2 and phase II antioxidant enzymes in neuroprotection. Prog Neurobiol 2013, 100:30-47.

65. Melnyk S, Fuchs GJ, Schulz E, Lopez M, Kahler SG, Fussell JJ, Bellando J, Pavliv O, Rose S, Seidel L, Gaylor DW, James SJ: Metabolic imbalance associated with methylation dysregulation and oxidative damage in children with autism. J Autism Dev Disord 2012, 42:367-377.

66. Rose S, Melnyk S, Trusty TA, Pavliv O, Seidel L, Li J, Nick T, James SJ: Intracellular and extracellular redox status and free radical generation in primary immune cells from children with autism. Autism Res Treatment 2012, 2012:986519.

67. Rose S, Melnyk S, Pavliv O, Bai S, Nick TG, Frye RE, James SJ: Evidence of oxidative damage and inflammation associated with low glutathione redox status in the autism brain. Trans/ Psychiatry 2012, 2:e134.

68. Pecorelli A, Leoncini S, De Felice C, Signorini C, Cerrone C, Valacchi G, Ciccoli L, Hayek J: Non-protein-bound iron and 4-hydroxynonenal protein adducts in classic autism. Brain Dev 2013, 35:146-154.
69. Laszlo A, Novak Z, Szollosi-Varga I, du Hai Q, Vetro A, Kovacs A: Blood lipid peroxidation, antioxidant enzyme activities and hemorheological changes in autistic children. Ideggyogy Sz 2013, 66:23-28.

70. Meguid NA, Dardir AA, Abdel-Raouf ER, Hashish A: Evaluation of oxidative stress in autism: defective antioxidant enzymes and increased lipid peroxidation. Biol Trace Elem Res 2011, 143:58-65.

71. Frustaci A, Neri M, Cesario A, Adams JB, Domenici E, Dalla Bernardina B, Bonassi S: Oxidative stress-related biomarkers in autism: Systematic review and meta-analyses. Free Radic Biol Med 2012, 52:2128-2141.

72. Chauhan A, Audhya T, Chauhan V: Brain region-specific glutathione redox imbalance in autism. Neurochem Res 2012, 37:1681-1689.

73. Anitha A, Nakamura K, Thanseem I, Yamada K, Iwayama Y, Toyota T, Matsuzaki H, Miyachi T, Yamada S, Tsujii M, Tsuchiya KJ, Matsumoto K, Iwata Y, Suzuki K, Ichikawa H, Sugiyama T, Yoshikawa T, Mori N: Brain regionspecific altered expression and association of mitochondria-related genes in autism. Mol Autism 2012, 3:12.

74. Guttula SV, Allam A, Gumpeny RS: Analyzing microarray data of Alzheimer's using cluster analysis to identify the biomarker genes. Int J Alzheimers Dis 2012, 2012:649456.

75. Lowery LA, Rubin J, Sive H: Whitesnake/sfpq is required for cell survival and neuronal development in the zebrafish. Dev Dyn 2007, 236:1347-1357.

76. Mytilinaios DG, Tsamis Kl, Nikolakaki E, Giannakouros T: Distribution of SRPK1 in human brain. J Chem Neuroanat 2012, 43:20-27.

77. Listerman I, Sun J, Gazzaniga FS, Lukas JL, Blackburn EH: The major reverse transcriptase-incompetent splice variant of the human telomerase protein inhibits telomerase activity but protects from apoptosis. Cancer Res 2013, 73:2817-2828.

78. Dormann D, Haass C: Fused in sarcoma (FUS): an oncogene goes awry in neurodegeneration. Mol Cell Neurosci 2013. doi:10.1016/j.mcn.2013.03.006.

79. Blechingberg J, Holm IE, Nielsen AL: Characterization and expression analysis in the developing embryonic brain of the porcine FET family: FUS, EWS, and TAF15. Gene 2012, 493:27-35.

80. Workman E, Kolb SJ, Battle DJ: Spliceosomal small nuclear ribonucleoprotein biogenesis defects and motor neuron selectivity in spinal muscular atrophy. Brain Res 2012, 1462:93-99.

81. Douglas AG, Wood MJ: RNA splicing: disease and therapy. Brief Funct Genomics 2011, 10:151-164.

82. Smith RM, Sadee W: Synaptic signaling and aberrant RNA splicing in autism spectrum disorders. Front Synaptic Neurosci 2011, 3:1.

83. Husseman JW, Hallows JL, Bregman DB, Leverenz JB, Nochlin D, Jin LW, Vincent I: Hyperphosphorylation of RNA polymerase II and reduced neuronal RNA levels precede neurofibrillary tangles in Alzheimer disease. J Neuropathol Exp Neurol 2001, 60:1219-1232.

84. Hong SK, Dawid IB: The transcriptional mediator component Med12 is required for hindbrain boundary formation. PLOS One 2011, 6:e19076.

85. Wang X, Yang N, Uno E, Roeder RG, Guo S: A subunit of the mediator complex regulates vertebrate neuronal development. Proc Natl Acad Sci USA 2006, 103:17284-17289.

86. Zhou H, Spaeth JM, Kim NH, Xu X, Friez MJ, Schwartz CE, Boyer TG: MED12 mutations link intellectual disability syndromes with dysregulated GLI3-dependent Sonic Hedgehog signaling. Proc Natl Acad Sci USA 2012, 109:19763-19768.

87. Mohibi S, Gurumurthy CB, Nag A, Wang J, Mirza S, Mian Y, Quinn M, Katafiasz B, Eudy J, Pandey S, Guda C, Naramura M, Band H, Band V: Mammalian alteration/deficiency in activation 3 (Ada3) is essential for embryonic development and cell cycle progression. J Biol Chem 2012, 287:29442-29456.

88. Chen Y, Wan B, Wang KC, Cao F, Yang Y, Protacio A, Dou Y, Chang HY, Lei M: Crystal structure of the N-terminal region of human Ash2L shows a winged-helix motif involved in DNA binding. EMBO Rep 2011, 12:797-803

89. Nicholas B, Rudrasingham V, Nash S, Kirov G, Owen MJ, Wimpory DC: Association of Per1 and Npas 2 with autistic disorder: support for the clock genes/social timing hypothesis. Mol Psychiatry 2007, 12:581-592.

90. Yamamoto K, Shibata F, Miyasaka N, Miura O: The human perforin gene is a direct target of STAT4 activated by IL-12 in NK cells. Biochem Biophys Res Commun 2002, 297:1245-1252.

91. Shukla S, Oberdoerffer S: Co-transcriptional regulation of alternative pre-mRNA splicing. Biochim Biophys Acta 1819, 2012:673-683.

92. Kornblihtt AR: Coupling transcription and alternative splicing. Adv Exp Med Biol 2007, 623:175-189. 
93. Guffanti G, Strik Lievers L, Bonati MT, Marchi M, Geronazzo L, Nardocci N, Estienne M, Larizza L, Macciardi F, Russo S: Role of UBE3A and ATP10A genes in autism susceptibility region $15 q 11-q 13$ in an Italian population: a positive replication for UBE3A. Psychiatry Res 2011, 185:33-38.

94. Baron CA, Tepper CG, Liu SY, Davis RR, Wang NJ, Schanen NC, Gregg JP: Genomic and functional profiling of duplicated chromosome 15 cell lines reveal regulatory alterations in UBE3A-associated ubiquitinproteasome pathway processes. Hum Mol Genet 2006, 15:853-869.

95. Basu SN, Kollu R, Banerjee-Basu S: AutDB: a gene reference resource for autism research. Nucleic Acids Res 2009, 37:832-836.

96. O'Roak BJ, Deriziotis P, Lee C, Vives L, Schwartz JJ, Girirajan S, Karakoc E, Mackenzie AP, Ng SB, Baker C, Rieder MJ, Nickerson DA, Bernier R, Fisher SE, Shendure J, Eichler EE: Exome sequencing in sporadic autism spectrum disorders identifies severe de novo mutations. Nat Genet 2011, 43:585-589.

97. O'Roak BJ, Vives L, Girirajan S, Karakoc E, Krumm N, Coe BP, Levy R, Ko A, Lee C, Smith JD, Turner EH, Stanaway IB, Vernot B, Malig M, Baker C, Reilly B, Akey JM, Borenstein E, Rieder MJ, Nickerson DA, Bernier R, Shendure J, Eichler EE: Sporadic autism exomes reveal a highly interconnected protein network of de novo mutations. Nature 2012,485:246-250.

98. Yamada M, Naiki H: Cerebral amyloid angiopathy. Prog Mol Biol Trans/ Sci 2012, 107:41-78.

99. Ji L, Chauhan A, Muthaiyah B, Wegiel J, Chauhan V: Gelsolin levels are increased in the brain as a function of age during normal development in children that are further increased in Down syndrome. Alzheimer Dis Assoc Disord 2009, 23:319-322.

100. Furukawa K, Fu W, Li Y, Witke W, Kwiatkowski DJ, Mattson MP: The actinsevering protein gelsolin modulates calcium channel and NMDA receptor activities and vulnerability to excitotoxicity in hippocampal neurons. J Neurosci 1997, 17:8178-8186.

101. Paunio T, Kangas H, Heinonen O, Buc-Caron MH, Robert JJ, Kaasinen S, Julkunen I, Mallet J, Peltonen L: Cells of the neuronal lineage play a major role in the generation of amyloid precursor fragments in gelsolin-related amyloidosis. J Biol Chem 1998, 273:16319-16324.

102. Vouyiouklis DA, Brophy PJ: A novel gelsolin isoform expressed by oligodendrocytes in the central nervous system. J Neurochem 1997, 69:995-1005.

103. Arun V, Wiley JC, Kaur H, Kaplan DR, Guha A: A novel neurofibromin (NF1) interaction with the leucine-rich pentatricopeptide repeat motifcontaining protein links neurofibromatosis type 1 and the French Canadian variant of Leigh's syndrome in a common molecular complex. J Neurosci Res 2013, 91:494-505.

104. Kaya N, Colak D, Albakheet A, Al-Owain M, Abu-Dheim N, Al-Younes B, Al-Zahrani J, Mukaddes NM, Dervent A, Al-Dosari N, Al-Odaib A, Kayaalp IV, Al-Sayed M, Al-Hassnan Z, Nester MJ, Al-Dosari M, Al-Dhalaan H, Chedrawi A, Gunoz H, Karakas B, Sakati N, Alkuraya FS, Gascon GG, Ozand PT: A novel $\mathrm{X}$-linked disorder with developmental delay and autistic features. Ann Neurol 2012, 71:498-508.

105. Vogl MR, Reiprich S, Kuspert M, Kosian T, Schrewe H, Nave KA, Wegner M: Sox 10 cooperates with the mediator subunit 12 during terminal differentiation of myelinating glia. J Neurosci 2013, 33:6679-6690.

106. O'Roak BJ, Vives L, Fu W, Egertson JD, Stanaway IB, Phelps IG, Carvill G, Kumar A, Lee C, Ankenman K, Munson J, Hiatt JB, Turner EH, Levy R, O'Day DR, Krumm N, Coe BP, Martin BK, Borenstein E, Nickerson DA, Mefford HC, Doherty D, Akey JM, Bernier R, Eichler EE, Shendure J: Multiplex targeted sequencing identifies recurrently mutated genes in autism spectrum disorders. Science 2012, 338:1619-1622.

107. Choi HK, Choi KC, Yoo JY, Song M, Ko SJ, Kim CH, Ahn JH, Chun KH, Yook Jl, Yoon HG: Reversible SUMOylation of TBL1-TBLR1 regulates beta-catenin -mediated Wnt signaling. Mol Cell 2011, 43:203-216.

108. Rebenko-Moll NM, Liu L, Cardona A, Ransohoff RM: Chemokines, mononuclear cells and the nervous system: heaven (or hell) is in the details. Curr Opin Immunol 2006, 18:683-689.

109. Vargas DL, Nascimbene C, Krishnan C, Zimmerman AW, Pardo CA: Neuroglial activation and neuroinflammation in the brain of patients with autism. Ann Neurol 2005, 57:67-81.

110. Sahin M: Targeted treatment trials for tuberous sclerosis and autism: no longer a dream. Curr Opin Neurobiol 2012, 22:895-901.

111. Geschwind DH: Autism: many genes, common pathways? Cell 2008, 135:391-395.

112. Onore $C$, Careaga $M$, Ashwood $P$ : The role of immune dysfunction in the pathophysiology of autism. Brain Behav Immun 2012, 26:383-392.
113. Andersson O, von Euler G: Characterization and expression of the gene encoding membralin, an evolutionary conserved protein expressed in the central nervous system. Brain Res Gene Expr Patterns 2002, 1:205-212.

114. Chen YC, Davidson B, Cheng CC, Maitra A, Giuntoli RL 2nd, Hruban RH, Wang TL, Shih IM: Identification and characterization of membralin, a novel tumor-associated gene, in ovarian carcinoma. Biochim Biophys Acta 2005, 1730:96-102.

115. Sebat J, Lakshmi B, Malhotra D, Troge J, Lese-Martin C, Walsh T, Yamrom B, Yoon S, Krasnitz A, Kendall J, Leotta A, Pai D, Zhang R, Lee YH, Hicks J, Spence SJ, Lee AT, Puura K, Lehtimaki T, Ledbetter D, Gregersen PK, Bregman J, Sutcliffe JS, Jobanputra V, Chung W, Warburton D, King MC, Skuse D, Geschwind DH, Gilliam TC, et al: Strong association of de novo copy number mutations with autism. Science 2007, 316:445-449.

doi:10.1186/2040-2392-4-30

Cite this article as: Stamova et al.: Evidence for differential alternative splicing in blood of young boys with autism spectrum disorders. Molecular Autism 2013 4:30.

\section{Submit your next manuscript to BioMed Central and take full advantage of:}

- Convenient online submission

- Thorough peer review

- No space constraints or color figure charges

- Immediate publication on acceptance

- Inclusion in PubMed, CAS, Scopus and Google Scholar

- Research which is freely available for redistribution 